University at Buffalo School of Law

Digital Commons @ University at Buffalo School of Law

Journal Articles

Faculty Scholarship

Fall 2002

\title{
The New Environmental Law: Forest Certification
}

Errol E. Meidinger

University at Buffalo School of Law

Follow this and additional works at: https://digitalcommons.law.buffalo.edu/journal_articles

Part of the Environmental Law Commons, and the Forest Management Commons

\section{Recommended Citation}

Errol E. Meidinger, The New Environmental Law: Forest Certification, 10 Buff. Envtl. L.J. 211 (2002).

Available at: https://digitalcommons.law.buffalo.edu/journal_articles/554

\section{C. ${ }_{\text {COPYRIGHT }}^{\text {N }}$}

This Article is brought to you for free and open access by the Faculty Scholarship at Digital Commons @ University at Buffalo School of Law. It has been accepted for inclusion in Journal Articles by an authorized administrator of Digital Commons @ University at Buffalo School of Law. For more information, please contact lawscholar@buffalo.edu. 


\title{
The NeW ENVIRONMENTAL LAW: FOREST CERTIFICATION*
}

\author{
Errol E. Meidinger“*
}

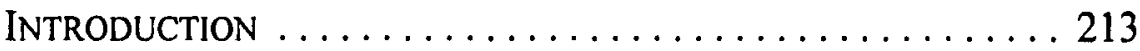

The Basics of Forest CertifiCation $\ldots \ldots \ldots \ldots \ldots \ldots 215$

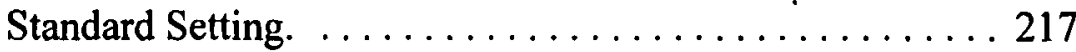

Certification. .........................221

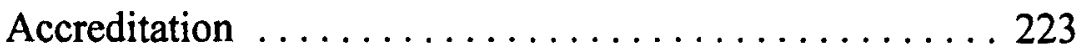

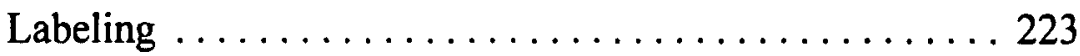

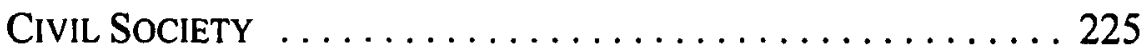

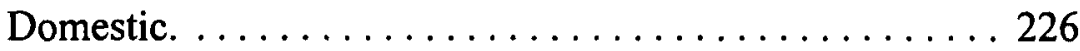

Global. ......................... 230

Facilitating Elements $\ldots \ldots \ldots \ldots \ldots \ldots \ldots \ldots 232$

Salient Characteristics ................. 235

- Revision and expansion of a paper first presented at the International Conference on Social and Political Dimensions of Forest Certification, University of Freiburg, Germany, June 20-22, 2001. Portions of the paper are forthcoming under different titles in Errol Meidinger, Chris Elliott, and Gerhard Oesten, eds., Social and Political Dimensions of Forest Certification, 2003. Comments by the participants in the Freiburg Conference, the Sustainable Environmental Law Conference at SUNY-Buffalo, the Law Faculty Workshop at SUNY-Buffalo, and the Harrison Program on the Global Future at the University of Maryland were very helpful in developing the paper. Special thanks to David Westbrook, Alex Ziegert, and Karol Soltan for their thoughtful critiques, and to Adam Rizzo and Tatania Vostok for research assistance. This paper was made possible by research funding from the Baldy Center for Law and Social Policy, State University of New York at Buffalo, for which the author is most grateful.

- $\quad$ Professor and Vice Dean of Law, State University of New York at Buffalo School of Law. Email: eemeid@buffalo.edu Web: http://www.law.buffalo.edu leemeid 


\section{BUFFALO ENVIRONMENTAL LAW JOURNAL [Vol.10}

Forest Certification and Global Civil Society $\ldots \ldots . .236$

Actors and Organization. .................. 236

Substantive Values. . . . . . . . . . . . . . . 241

Methods ................................ 244

Role in Global Society .................. 250

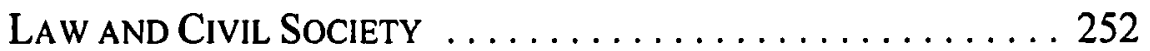

Domestic ........................ 252

Global .............................. 257

Basic Conceptual Perspectives . . . . . . . . . . . . 260

ENVIRONMENTAL LAW AND CIVIL SOCIETY $\ldots \ldots \ldots \ldots 262$

Domestic .......................... 262

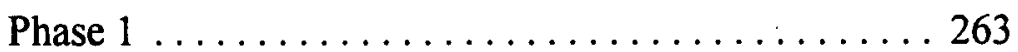

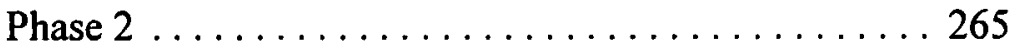

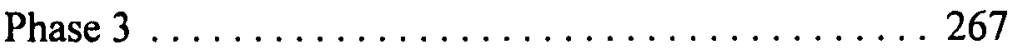

Global .............................. 276

Forest Certification as ENVIRonmental LaW $\ldots \ldots \ldots 278$

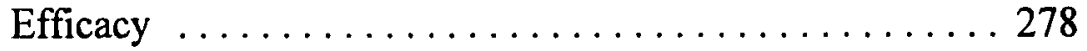

Internal . . . . . . . . . . . . . . . . . . . . 282

External ......................... 288

Adaptability . . . . . . . . . . . . . . . . . . . . 290

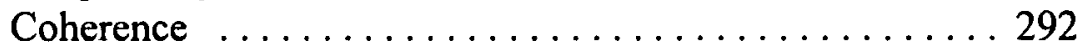

Integration . . . . . . . . . . . . . . . . . . 293

Federalism .......................... 296

(In)Determinacy . . . . . . . . . . . . . . . . . . . . . . . 297

Legitimacy ......................... 298 


\section{Introduction}

Forest certification is a process through which transnational networks of diverse actors set and enforce standards for the sustainable management of forests around the world. The central purpose of forest certification programs is to verify for interested outsiders that the management activities of certified enterprises are acceptable and appropriate. In doing so, certification programs take on important public roles. First, they define what kind of behavior is acceptable and appropriate. Some programs incorporate considerable public input and participation, others very little. Some stress multistakeholder decision-making while others rely almost entirely on industry associations or firms. No major certification program, however, relies primarily on the policy formation processes of government. ${ }^{1}$ Second, certification programs establish mechanisms to enforce their policies, and to provide public assurances that they are being met. Again, they place little or no reliance on existing governmental enforcement programs. Rather, they devise their own organizational monitoring, auditing, and adjudication ${ }^{2}$ systems, and seek to establish credibility independent of government agencies. ${ }^{3}$

1 I use the term "government" to refer to the organizational structures of nation states, including their subunits and intergovernmental organizations. My use of the term reflects a desire to keep to a minimum the theoretical implications often associated with "the state" in Western, and particularly European thought, and also to allow for the great variability and frequent lack of coordination among agencies and institutions operating under the rubric of government.

2 Adjudication is used here in the commonplace American sense, to refer to decisions about whether particular cases meet general criteria, regardless of whether the decision maker is a judge, an administrative official, or an actor outside the government.

3 There are some partial exceptions to this statement- primarily the emergent Pan European Forest Certification Council program. Peter Sprang, Aspects of Quality Assurance Under the Certification Schemes FSC and PEFC, Diplomarbeit, University of Freiburg Institute for Forestry Economics Website, available at http://www.ruf.uni-freiburg.de/forstoko/veroff/arbeitspapier.html (2001); and the longer standing Lembaga Ekolabel Indonesia (LEI). Christopher Elliott, Forest Certification: A Policy Perspective, Center for International Forestry Research in 


\section{BUFFALO ENVIRONMENTAL LAW JOURNAL [Vol.10}

Products from certified forestry enterprises are generally entitled to display a logo signifying their propriety.

The environmental policy-making and enforcement functions undertaken by certification programs have been performed primarily by governments for at least the past century, and longer in some societies. Hence the initial theoretical challenge is how to conceptualize certification programs. Given that they are not governmental initiatives, much of the existing literature describes certification programs as 'market mechanisms' or 'market driven.' But these descriptions are true only in the loosest sense, in that certification programs seek to achieve their goals by restructuring producers' relationships to consumers through markets. At base, the groups that have pioneered certification programs, primarily the Forest Stewardship Council ${ }^{4}$ and affiliated advocacy organizations such as the World-Wide Fund for Nature, Rainforest Alliance, and Friends of the Earth, ${ }^{5}$ have not been responding to market forces. Rather, they have sought to harness market forces to the pursuit of environmental protection and other social and ethical goals. Their objective has been to institute predictable, long term ordering of the behavior of forestry

Jakarta, Indonesia (2000). (Originally published as a Ph.D. Thesis, Forest Certification: Analysis from a Policy Network Perspective. École Polytechnique Fédérale De Lausanne, 1999). Both of these programs, however, have been driven by the civil society movement, and can be understood as catch-up efforts by governmental agencies to recapture a leading role in the field.

4 The Forest Stewardship Council is an international organization founded in 1993 to promote the sustainable management of forests around the world. Although it has received support from foundations, environmental Nongovernmental organizations, particularly the World Wildlife Fund, and some mostly European governments, it is a free standing organization. It devotes its resources primarily to the setting of forest management standards and to the accreditation of certification organizations whose role it is to determine whether particular management organizations meet the standards. For more thorough descriptions, see the FSC website available at $\mathrm{http}: / \mathrm{www}$.fscoax.org/principal.htm or Errol Meidinger, 'Private' Environmental Regulation, Human Rights, and Community, 7 BuFf. ENVTL. L.J. 123, 130-82 (1999).

5

Elliott, supra note 3. 
firms-i.e., "social regulation of the market". ${ }^{6}$ Hence, while market forces are undoubtedly crucial to the success of certification programs, market constructs provide only a partial understanding of the social dynamics of forest certification.

One of the primary theoretical constructs used to conceptualize organized efforts to shape social behavior beyond the domains of government and market—and one occasionally invoked by promoters of forest certification-is that of 'civil society. ${ }^{7}$ The goal of this paper is to elucidate both forest certification and the concept of civil society by locating forest certification in the context of civil society theory. Moreover, since certification programs seek to achieve the long term regulation of forest management in a predictable, law-like manner, the paper explores the question of the degree to which certification programs can be seen as modifying or actually creating law. Finally, it examines forest certification in terms of some of the critical analytical perspectives characteristic of legal scholarship.

\section{The Basics of Forest Certification}

What does it mean to 'certify' a forest? Obviously, it does not mean certifying the forest per se, since that would be unintelligible. Rather, it means certifying that the people responsible for a forest are taking care of it properly. Thus, from a commonsensical perspective forest certification implies that: (1) we understand what it means to take care of a forest properly and that (2) a trustworthy person who understands proper forest management (3) visits the forest and assesses the work of the people who manage it and (4) certifies to

$6 \quad$ Virginia Haufler, New Forms of Governance: Certification Regimes as Social Regulation of the Market, in SOCIAL AND POLITICAL DIMENSIONSOF FOREST CERTIFICATION, 237-247 (Errol E. Meidinger, et al. eds., 2003). 7 The term is used broadly here to include a variety of formulations which
seem to be based on the same basic set of ideas, such as the "third system" discussion represented by Marc Nerfin, Neither Prince nor Merchant-An Introduction to the Third System, IFDA Dossier, No. 56:3-29. (1986); and David Korten in GeTTING TO THE 21ST CENTURY: VOLUNTARY ACTION AND THE GLOBAL AGENDA (1990). 


\section{BUFFALO ENVIRONMENTAL LAW JOURNAL [Vol.10}

others that things are being done correctly. Conversely, if the forest is not being managed properly, certification is withheld.

The idea of forest certification gained currency in a series of discussions among North American and European environmental activists and socially conscious tropical hardwood users in the1980s and early 1990s. It was particularly attractive to environmentalists because they saw it as a way of responding to the widely perceived problem of tropical deforestation and yet not supporting a boycott of all tropical timber, as had been proposed by some environmental groups in developed countries. The great advantage of certification was that it could provide a means to identify tropical timber that was properly grown and harvested, thus allowing northern consumers to buy tropical hardwoods without feeling that they were contributing to tropical deforestation. It soon became apparent, however, that to be perceived as fair, such a program would have to apply to tropical and non-tropical timber alike, since there was widespread and justifiable skepticism about the sustainability of much management in temperate and boreal forests.

Starting with the Forest Stewardship Council (FSC) in 1993, forest certification programs proliferated rapidly. Today there are anywhere between six and twenty or more, depending on how one counts. ${ }^{8}$ At a more general level, however, they are converging around

8 The most recent report of the Confederation of European Paper Industries lists 20 programs: (1) FSC International, (2) PEFC International, (3) American Forest \& Paper Association Sustainable Forestry Initiative, (4) American Tree Farm System, (5) Czech Council of the National Certification Center, (6) Finnish Forest Certification Council, (7) Lembaga Ekolabel Indonesia (LEI), (8) Living Forests Norway (PEFC affiliated), (9) PEFC Austria, (10) PEFC Council of Latvia, (11) PEFC France, (12) PEFC Germany, (13) PEFC Sweden, (14) PEFC Switzerland and HWK Zertifizierungsstelle, (15) PEFC UK, (16) Standards Council of Canada, (17) Associacão Brasileira de Normas Technicas, (18) CEF-Certificación Española Forestal, (19) Conselho Da Fileira Florestal Portuguesa, and (20) Malaysian Timber Certification Council. Many of these are affiliated with and were developed by the PEFC, and therefore this may be seen as an overcount; on the other hand, as the FSC's national and regional standard setting efforts progress and potentially develop increased autonomy, it could also come to be seen as an undercount. In any event, the list does give a sense of the fluidity of 
two alliances, one centered on the NGO-oriented ${ }^{9}$ FSC and the other centered on the forest production-oriented Pan European Forest Certification Council (PEFC).

As certification programs have proliferated, they have formed around a common set of institutional functions: standard setting, certification, accreditation of certifiers, product labeling, and administration. ${ }^{10}$ The remainder of this section briefly describes these functions and how they are being carried out by existing certification programs. Because the FSC has been the driving force and the model in terms of which competing certification programs define themselves, the FSC's practices are used to exemplify certification institutions.

\section{Standard Setting}

All certification programs set standards for forest management on the basis of which forest management operations (FMOs) are to be

program boundaries in the field. Confederation of European Paper Industries, Comparative Matrix of Forest Certification Schemes,(2001) available at http://www.cepi.org/htdocs/pdfs/newsletters/pub_a29.pdf

9 'NGO' stands for 'non-governmental organization' and is used in this paper primarily to reference environmental protection and social justice advocacy organizations.

10 Forest certification programs were able to draw upon a long legacy of certification programs in other sectors. In the U.S., for example, Underwriters Laboratories (UL) had been setting safety standards for electrical appliances and monitoring manufacturer compliance for almost a century when forest certification began. The National Fire Protection Association (NFPA) had been setting fire safety standards for buildings (although not certifying them) for nearly as long. The Joint Commission on the Accreditation of Healthcare Organizations (JCAHO) had been setting standards for and certifying health care organizations for over four decades. There are certainly hundreds and probably thousands of such programs around the world. See e.g.,Ross E. CHEIT, SETTING SAFETY STANDARDS: REgUlation IN THE PUbliC AND PRIVATE SECTORS (1990). These programs have gradually converged on a number of forms of standardization. Much of this standardization has been brought under the umbrella of the International Organization for Standardization (ISO), which is a global federation of approximately 140 national standard setting bodies that has developed international standards for countless types of industries and practices. 


\section{BUFFALO ENVIRONMENTAL LAW JOURNAL [Vol.10}

certified. They all orient themselves in terms of the goal of 'sustainable forest management' (SFM), although the FSC is unwilling to claim that it can certify that forest management will in fact turn out to be sustainable. SFM has been the subject of continuing debate in the larger field of forest policy and has undergone considerable change in recent decades. The basic tendency of that change has been to broaden the set of considerations that forest managers must take into account, from (1) ensuring a steady flow of timber from the forest, to (2) protecting the range of ecological functions, components, and services provided by the forest, to (3) protecting the many societal interests tied to the forest.

Forest certification programs have relied on two different types of standards in pursuing SFM: (1) performance outcomes or (2) management systems. Performance standards require the achievement of concrete conditions in the forest or in human organizations related to the forest. For example, the FSC's principles and criteria require that FMOs:

(1) comply with applicable laws and treaties;

(2) ensure that long term tenure and use rights are clearly established;

(3) recognize and respect indigenous peoples' legal and customary rights,

(4) maintain or enhance the social and economic wellbeing of forest workers and local communities;

(5) use forest resources efficiently to ensure economic viability;

(6) conserve biodiversity and protect ecological functions;

(7) implement a long term management plan;

(8) monitor management performance and environmental and social impacts;

(9) protect high conservation value forests (e.g., those that contain endangered biota or fulfill crucial ecological or social functions);

(10) and manage plantation forests so as to reduce pressure 
on natural forests."

These goals are further defined by more specific criteria. Among the criteria for conserving biodiversity, for example, are the following:

6.2 Safeguards shall exist which protect rare, threatened and endangered species and their habitats (e.g., nesting and feeding areas). Conservation zones and protection areas shall be established, appropriate to the scale and intensity of forest management and the uniqueness of the affected resources. Inappropriate hunting, fishing, trapping and collecting shall be controlled.

6.3 Ecological functions and values shall be maintained intact, enhanced, or restored, including:

a) Forest regeneration and succession.

b) Genetic, species, and ecosystem diversity.

c) Natural cycles that affect the productivity of the forest ecosystem.

6.4 Representative samples of existing ecosystems within the landscape shall be protected in their natural state and recorded on maps, appropriate to the scale and intensity of operations and the uniqueness of the affected resources.

6.5 Written guidelines shall be prepared and implemented to: control erosion; minimize forest damage during harvesting, road construction, and all other mechanical disturbances; and protect water resources....

There are approximately 50 such criteria for the various

" See the FSC Website, available at http://www.fscoax.org/principal.htm for a full quotation of the FSC Principles. There were originally nine principles, and the ninth and tenth have been debated and revised in recent years. 
principles, and they are further elaborated by locally specific standards.

A management system standard, on the other hand, focuses on defining management processes and responsibilities within the FMO. The most influential such standard is the ISO 14001 environmental management standard (EMS) recently developed by the International Organization for Standardization (ISO). The basic idea is to require the FMO to define and implement a specific set of responsibilities and processes for dealing with environmental and related issues. EMSs typically include arrangements for ascertaining the organization's environmental effects, planning how to increase the positive ones and/or decrease the negative ones, and achieving 'continuous improvement.' The underlying argument for EMSs is that harnessing the planning and control capacities of the FMO to the goal of improving environmental performance may achieve better results in a dynamic and uncertain environment than would a reliance on fixed performance standards. ${ }^{12}$ Several industry based certification programs, such as that of the Canadian Standards Association ${ }^{13}$ and the Sustainable Forestry Initiative ${ }^{14}$ have relied heavily on management system standards, although they are also adding performance oriented standards.

As the distinction between performance and management system standards suggests, there are also different levels of generality at which standards can be set: (1) for the program as a whole, (2) for local areas covered by of the program, or (3) for specific FMOs. In practice, organizations at each of these levels usually also play a role in standard setting, in part because it is impossible to set standards in

\footnotetext{
12 See e.g.,Cary Coglianese, \& Jennifer Nash, Regulating FrOM THE INSIDE: CAN ENVIRONMENTAL MANAGEMENT SYSTEMS ACHIEVE POLICY GOALS? Washington, DC: Resources for the Future (2001).

13 Canadian Standards Association Standard CAN/CSA Z808/Z809-2001. Available at http://www.csa.ca.

14 American Forest \& Paper Association Sustainable Forestry Initiative. See website available at http://www.afandpa.org/Content/NavigationMenu/ Environment_and_Recycling/SFI/SFI.htm
} 
sufficient breadth and detail to dispose of every possible situation. Given the variability of local situations around the world and rapid changes in knowledge, it often makes sense to leave some important details to local decision makers.

All existing certification programs employ each of the standard setting options described above (i.e., central/local/FMO and performance/management system) to at least some degree, but in quite different mixes. Programs also vary by which kinds of actors participate at each level. While they all provide for some degree of stakeholder input, the amount varies greatly, from the formal tripartite environmental/social/economic structure of the FSC to the industrydominated structures of the Sustainable Forestry Initiative and the Pan European Forest Certification Council. ${ }^{15}$ Finally, the standards of forest certification programs vary considerably in scope. While most standards focus on forestry practices and biological conditions, some also include social justice concerns such as the protection of laborers, indigenous peoples and local communities.

\section{Certification}

Certification of FMOs is the core function of forest certification programs. To carry it out the programs must define organizational processes and relationships likely to assure compliance with applicable forest management standards. To be useful, these arrangements must also persuade outside observers that they are likely to result in a high degree of compliance-i.e., they must be credible. While all forest certification programs rely to some extent on the internal processes of FMOs, they also rely on outside monitoring. The most rigorous approach is 'third party verification,' wherein a person or organization that is neither part of the FMO, nor one of its customers or suppliers, is given authority to assess compliance with the program standards. Not all certification programs require third party verification, however. Even

\footnotetext{
15 The Pan European Forest Certification Program available at http://www.pefc.org
} 


\section{BUFFALO ENVIRONMENTAL LAW JOURNAL [Vol.10}

where it is used variations in how it is implemented may lead to differences in reliability. Perhaps the most important variable is the degree of control that the forestry enterprise can exercise over the certification body and its findings. Some programs give FMOs much more control over the selection, terms of employment, and findings of certifiers than do others. Overall, there has been a steady tendency among forest certification programs to institute third party verification, but there are still enormous differences among them. Even the most rigorous programs still face questions of credibility deriving from the fact that certifiers are paid by the FMOs seeking certification.

At present, the FSC operates the most demanding certification program, which has the following characteristics. Certification is done by a small number of organizationally independent certification organizations. The certifiers use multi-disciplinary teams to review the on-the-ground management operations of each forestry operation that applies for certification. A typical FSC certification would involve roughly the following steps:

(1) preliminary discussions between the potential applicant and one or more certifiers, including indications of what changes the applicant likely will have to make to achieve certification;

(2) submission of an application to a certifier, including documentation of the applicant's operation;

(3) negotiation of a budget and other contractual terms of the assessment, possibly including a 'scoping' process;

(4) on-the-ground field assessment, including required consultations with local stakeholders; ${ }^{16}$

(5) preparation of a draft assessment report by the certifier;

(6) peer review of the report by two or three independent specialists;

(7) discussion of possible terms and conditions of

16 Most stakeholder consultation processes to date have been developed by certification organizations. The FSC is now working to systematize information on and approaches to local consultation. 
certification with the applicant;

(8) a final certification decision (see below);

(9) certificate issuance, processing of final payments, further certification contracts, press releases, etc; and

(10) random annual follow-up audits.

Certifiers have several options in reaching a final decision on certification: (1) approve an application unconditionally; (2) grant provisional approval on condition that certain corrective actions are taken within a certain time; (3) indicate that approval will be granted after certain preconditions are met; or (4) deny the application. Certificates ordinarily last for five years, after which time a thoroughgoing reassessment occurs prior to renewal.

\section{Accreditation}

When programs embrace third party certification, an important question immediately arises as to who should be qualified-i.e., be 'accredited'-to serve as a certifier. Some certification programs, notably the FSC, make their own accreditation determinations, while others use accreditation organizations that developed for other purposes (sometimes under the ISO umbrella), and some allow FMOs to make their own determinations as to who qualifies as a certifier.

\section{Labeling}

The last key element of a forest certification program is how it ties wood products sold in consumer markets to certified forestry operations. All major certification programs have now developed programs for attaching their labels to wood products. The FSC logo, for example, is a somewhat deciduous looking conifer joined to the long end of a check mark: 


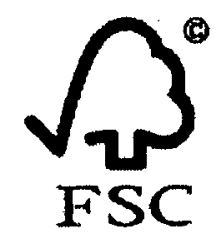

The American Forest and Paper Association recently changed its logo for the Sustainable Forestry Initiative from one containing both kinds of trees with a bear and fish circling them, presumably invoking an ecosystem image, to one of a conifer inside what appears to be a flame, presumably an eternal one:

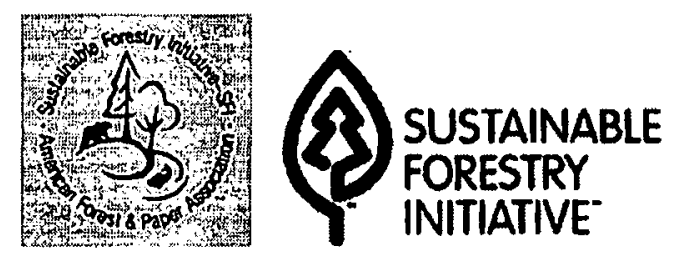

The PEFC has taken elements of them all and given the logo a sense of cycling:

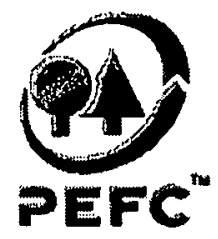

Their rules for determining which wood products qualify, and particularly how those wood products must be traced through the chain of production ('chain of custody requirements'-COC), are quite variable and remain under development, but are widely seen as a key element of effective certification.

The above paragraphs describe the key institutional elements of forest certification programs, they say little about how the programs can have come into being outside traditional governmental agencies 
or what their role is in the governance of society. The next two sections begin to fill in the picture with discussions of civil society and its increasingly global character.

\section{Civil Society}

In the mid-1980's I had a memorable conversation with two colleagues in my university's Native American Studies Program, Professors John Mohawk and Oren Lyons. We were discussing a possible joint course in American Indian Law. As we talked about Native land claims in the US, our conversation turned to the efforts of the Brazilian government at the time to remove indigenous peoples from their land in the Amazon rain forest. When I expressed pessimism about the natives' prospects, Oren surprised me with his confident reply. He said something like, "The Brazilian government should know they can't keep doing that. The whole world is watching, and the whole world knows this is wrong. We'll see it on TV tomorrow, and we can make a lot of trouble for them." When I asked how such trouble would be made, he and John offered a variety of examples, including picketing Brazilian embassies, protesting at the UN (where Oren would soon be giving a speech), pressuring the World Bank, and possibly provoking consumer boycotts. ${ }^{17}$

When I countered that the major media might not even publicize the land battles in Brazil, John replied with his usual droll humor: "Well, we have computers, too. Usually we just set our coffee on them, but we do know how to turn them on." The "we" they were referring to was a network of indigenous peoples and their allies around the world. Oren looked into the northern distance out my office window and noted that the Sami people of Scandinavia would

17 I cannot remember whether they listed the possibility of dealing directly with the corporations doing business in Brazil, although I do not think they did. Today they probably would mention this option in the same sentence. 


\section{BUFFALO ENVIRONMENTAL LAW JOURNAL [Vol.10}

be just as willing to join the battle as the Haudenosaunee, ${ }^{18}$ since all indigenous peoples have essentially similar claims to justice among the peoples of the world.

My colleagues might resist being described as part of a civil society movement, since, like most indigenous groups in North America, the Haudenosaunee prefer to define themselves as sovereign. ${ }^{19}$ Yet, the expectations, processes, and structures they were describing are very consistent with what is coming to be called global civil society. Before describing the global variant, however, it is useful to provide a brief overview of the traditional, more locally oriented concept of civil society.

\section{Domestic}

Like "sovereignty," the term "civil society" is an evolving and often contested construct whose meaning has varied in different times and places. ${ }^{20}$ In modern academic discussions it generally refers to a sphere of social life that is public, but outside the sphere of government. Most references also exclude the realm of intimate associations, although American commentators sometimes include the family in discussions of civil society. ${ }^{21}$ In addition, with the exception

18 "Haudenosaunee" is the proper name for the people whom the Europeans labeled the "Iroquois." The latter term, which translates as "real adders," came from the Algonquins, who are traditional enemies of the Haudenosaunee. John C. Mohawk, Iroquois Confederacy, in ENCYCLOPEDIA OF NORTH AMERICAN INDIANS 298 (1996).

19 The Haudenosaunee are organized as a federation of six nations (the Cayuga, Mohawk, Oneida, Onondaga, Seneca, and Tuscarora). The Tuscarora migrated from North Carolina and joined it in the early 18th century. The Confederation issues a single passport, which has been accepted by many nations around the world. Personal communications with Oren Lyons \& John Mohawk.

20 E.g., J. EHRENBERG, CIVIL SOCIETY: THE CRITICAL HISTORY OF AN IDEA (1999).

21 American commentators discussing domestic policy tend to include the family in civil society institutions because of its importance in producing and reproducing patterns of societal relationships. See generally, Linda C. McClain \& James E. Fleming, Some Questions for Civil Society-Revivalists, 75 CHI.-KENT L. 
of neo-liberals, most commentators treat civil society as distinct from typical market relationships, which focus on matching prices and quantities to facilitate the exchange of goods and services. ${ }^{22}$ Diamond offers a relatively conventional definition:

[Civil Society] is distinct from "society" in general in that it involves citizens acting collectively in a public sphere to express their interests, passions, and ideas, exchange information, achieve mutual goals, make demands on the state, and hold state officials accountable. Civil society is an intermediary entity, standing between the private sphere and the state. Thus, it excludes individual and family life, inward-looking group activity (e.g. recreation, entertainment, or spirituality), the forprofit-making enterprise of individual business firms, and political efforts to take control of the state. ${ }^{23}$

Most theorists also portray civil society relationships as voluntary or un-coerced..$^{24}$ Although the true degree of voluntariness of some civil society relationships is subject to question, they generally lack the sanctions associated with government directives. Nonetheless, civil society organizations have long been viewed as playing a powerful role in steering the course of society. Gramsci, for example, depicted civil society organizations (epitomized by the Catholic Church) as achieving a high level of social influence by exercising cultural leadership ("hegemony") despite their general lack of state power. ${ }^{25}$

REV. 301, 301-335 (2000).

22 - E.g., Jean L. COHEN \& ANDREw A. ARATo, Civil SOciety AND POLITICAL THEORY (1992).

23 Larry Diamond, Toward Democratic Consolidation, in THE GLOBAL RESURGENCE OF DEMOCRACY 227, 228 (Larry Diamond \& Marc Platter, eds., 2d ed. 1996).

24 E.g., Michael Walzer, The Concept of Civil Society, in TowARD A GLOBAL CIVIL SOCIETY 7, 8 (Michael Walzer, ed., 1995).

25 ANTONIO GRAMSCI, THE MODERN PRINCE AND OTHER WRITINGS (International Publishers 1971) (1891); Kai Nielsen, Reconceptualizing Civil Society for Now: Some Somewhat Gramscian Turnings, in TOWARD A GLOBAL CIVIL SOCIETY 41 (Michael Walzer, ed., 1995). 
There are many types of civil society organizations. Walzer's examples (drawn from recent Eastern European experience) include "unions, churches, political parties and movements, cooperatives, neighborhoods, schools of thought, societies for promoting or preventing this and that". ${ }^{26}$ Mertus adds "non-governmental advocacy organizations, humanitarian service organizations, ... information and news media, educational associations, and certain forms of economic organization," leaving the specific nature of the last to be filled in. ${ }^{27}$ Conceptualizing the relationship of economic organizations to civil society is difficult, and may grow more so in the forest certification context, where trade associations and large corporations are becoming increasingly active. ${ }^{28}$ As Virginia Haufler suggests in a related context, it would not make sense to ignore business associations that are seeking to define the conditions of socially responsible commerce, even if they are driven by the quest for profit. ${ }^{29}$ Accordingly, my working approach is treat those aspects of business organization which are oriented to defining and institutionalizing public accountability outside government agencies as civil society actors. $^{30}$

While the overall sphere of civil society is portrayed as either value neutral ${ }^{31}$ or limited to very general values such as freedom and tolerance, ${ }^{32}$ specific civil society organizations are typically involved

$26 \quad$ Walzer, supra note 24 , at 8.

27 Julie Mertus, From Legal Transplants to Transformative Justice: Human Rights and the Promise of Transnational Civil Society, 14 AM. U. INTL'L L. REV. 1335, 1338 (1999).

28 Queena Sook Kim \& Jim Carlton, Battle Breaks Out Over Rival Seals for 'Green' Wood, Wall Street Journal, May 22, 2001, at B1.

29 Virginia Haufler, Self-Regulation and Business Norms: Political Risk, Political Activism, in PrIVATE AUTHORITY IN INTERNATIONAL AfFaIRS (A. Clair Cutler et al. eds., 1999).

30 The major risk, not addressed in this paper, is that business will so dominate civil society as to effectively destroy it. Ehrenberg, supra note 21 .

31 E.g., Amatai Etzioni, General Law in Civil Society, Good Society, and The Prescriptive State, 75 CHI.-KENT L. REV. 355, 355-377 (2000).

32 E.g., JOHN KEANE, DEMOCRACY AND CIVIL SOCIETY (1988). 
in "promoting or preventing this or that". ${ }^{33}$ They can be characterized by a commitment to particular substantive values, or visions of good society, and their purpose is to promote those visions. Thus they regularly engage in moral evaluation, often using the "mobilization of shame" to achieve their goals. ${ }^{34}$ Moreover, since civil society organizations promote moral evaluation, it is not surprising that they are also subject to it. Thus, their methods and strategies are inevitably vulnerable to critique, and they are frequently under pressure to improve them. Today the primary pressures are to be more transparent, democratic, and accountable ${ }^{35}$ and to eliminate exclusionary membership practices. ${ }^{36}$ Although these pressures may follow logically from the premise that civil society organizations are voluntary in nature, they are equally present for governments and to a lesser extent for firms.

Of course, civil society is a normative concept as well as an empirical one. Much of its appeal to modern thinkers rests in its role as a bulwark for human dignity and self-determination against both the state and the market. Although this function was already important for De Tocqueville (1875), it was critical in the rebirth and elaboration of the civil society movement in Eastern Europe during the late 1970s and 1980s. There, activist intellectuals developed the idea of civil society into a vision in which groups could self-organize in semiautonomous spaces outside the purview of the state. Their goal was not to "seize power" from the state, but rather to humanize the relationship between state and society by establishing new or renewed patterns of interaction in civil society. ${ }^{37}$ Their efforts became part of a larger European movement, which drew together Western European peace and Eastern European human rights organizations, and which

\footnotetext{
$33 \quad$ Walzer, supra note 24.

$34 \quad$ Mertus, supra note 27.

35 Id.

36 Susan H. Williams, A Feminist Reassessment of Civil Society, 72 IND. L. J. 417 (1997).
}

37 Adam Michnik, A New Evolutionism, in LETTERS FrOM PRISON AND OTHER ESSAYS, 135 (Maya Latynski, trans., 1985). 


\section{BUFFALO ENVIRONMENTAL LAW JOURNAL [Vol.10}

Mary Kaldor ${ }^{38}$ portrays as the birthplace of the modern civil society movement, although this portrayal may be overly Eurocentric. ${ }^{39}$

The importance and successes of the Eastern European civil society movement helped bring the concept back to the fore in academic discussions around the world. Among other things, it led many theorists to shift from a focus on "government(s)" to "governance", ${ }^{40}$ although other academic currents too numerous to note also contributed to this tendency. ${ }^{41}$ Research on civil society tends to focus on (1) the types of actors involved, (2) the substantive values they pursue, (3) the processes and methods they use, and (4) their relationships to other sectors of society. Each of these topics is discussed in the next section. While government, civil society, and the market can be distinguished analytically, however, they are operationally intertwined. The three spheres are also mutually interdependent; shifts in one are likely to affect the others, and often are intended to do so. Therefore researchers focusing on one sphere are wise to trace its relationships to others.

\section{Global}

In the course of the $1980 \mathrm{~s}$, various civil society and peace movements from different regions gradually drew together into a transnational network of relationships and actions. In fact, although not everyone recognized it at the time, regional and issue specific civil

Mary H. Kaldor, The Ideas of 1989: The Origins of the Concept of Global Civil Society, 9 TRANSNAT'L. L. \& CONTEMP. PROBS. 475, 475-88 (1999).

39 As my discussion with Professors Mohawk and Lyons indicates, there was a contemporaneous and perhaps even earlier movement among indigenous peoples. A definitive account of the origins of the global civil society movement is not an objective of this paper, however, and might not even be possible, given that the movement seems to have sprung up from many relatively independent social arenas.

40 E.g., JAMES N. ROSENAU \& ERNST-OTTO CZEMPIEL, EDS., GOVERNANCE WITHOUT GOVERNMENT: ORDER AND CHANGE IN WORLD POLITICS (1992).

41 ASEem PRAKash \& JefFrey A. HART, EDS., Globalization AND GOVERNANCE (1999). 
society movements were coalescing into a general, world-wide one. ${ }^{42}$ The goals, methods, networks, and social roles of the European civil society movement were increasingly linked to those of the indigenous peoples' network described at the beginning of this section and to other social movement networks around the world. ${ }^{43}$ Implicitly attributing the movement with institutional durability, academics and activists alike began to talk about "international" and "transnational" and even "global" civil society. Thus, although the civil society had been conceived, born, and raised inside territorially bounded states, it leapt the bounds of the states, and arguably the received conceptual framework as well. What, exactly, is distinctive about "global" civil society? According to Falk and Strauss, it is, quite simply, globalization:

Globalization has generated an emergent global civil society composed of transnational business, labor, media, religious, and issue-oriented citizen advocacy networks ... In one of the most significant, if not yet fully appreciated, developments of the postCold War era, global civil society-operating in collaboration with certain like-minded states-has become a formidable political presence in international life, pushing forward several key progressive initiatives in the international arena. ${ }^{44}$ (1998).

43 PAUl WAPNER, ENVIRONMENTAL ACTIVISM AND WORLd CiviC POlitics (1996); KECK \& SIKKINK supra note 43; Lucy Taylor, Globalization and Civil Society-Continuities, Ambiguities, and Realities in Latin America, 7 IND. J. Global Legal STUD. 269, 269-95 (1999); THE THIRD FORCE: THE RISE OF Transnational Civil Society (Ann M. Florini, ed., 2000). Nonetheless, as Taylor and Seligman illustrate, there were still significant differences in the causes of those using the term. Seligman argues that whereas in the East it was used to advance the cause of individualism, in the West it was used to advance the cause of communitarianism. ADAM SELIGMAN, THE IDEA OF CIVIL SOCIETY 203 (1992). Taylor provides an illuminating description of the typical differences between locally based social movements and internationally based NGOs in Latin America. $44 \quad$ Richard Falk \& Andrew Strauss, On the Creation of a Global Peoples Assembly: Legitimacy \& the Power of Popular Sovereignty, 36 STAN. J. INTL'L L. $191,194(2000)$. The initiatives they refer to include the global climate change 


\section{BUFFALO ENVIRONMENTAL LAW JOURNAL [Vol.10}

\section{Facilitating Elements}

Since globalization is a broad and somewhat wooly concept, it is helpful to list a few factors that seem to be key in the globalization of civil society. My goal is not to offer a persuasive causal account of globalization, nor even to rank factors in importance or time. Rather, it is to indicate that they have played causal roles and remain important characteristics of global civil society. These factors also play a central role in framing the strengths and weaknesses of global civil society regulatory programs.

Global Information Technologies: As Professors Lyons and Mohawk pointed out in the mid-80s, the rapid development of global information technologies was a critical factor in the creation of transnational coalitions and organizations. Included are technologies for gathering information (from traditional cameras to television cameras to satellite imaging to various kinds of emerging "real-time" sensors) and for communicating it (international newspapers and telecommunications systems, global television, the internet, and so on).

Critically important is the growing capacity of transnational advocacy groups to gather information, sometimes amounting to serious research, and communicate it on their own. Particularly important is their capacity to connect internationally marketed products to the local conditions under which they are produced. ${ }^{45}$

framework convention, the convention outlawing anti-personnel land mines, and the agreement to establish an international criminal court. The authors go on to argue that the time is ripe for a "global peoples' assembly." Id. at 196-204.

45 Peter Evans, Fighting Marginalization with Transnational Networks: Counter-Hegemonic Globalization, 29 CONTEMP. SOC. 230, 234 (2000). As Conca (2001) points out, this capacity to connect production conditions to consumption is made all the more essential by the enormous 'distancing' of production from consumption that comes with the creation of global production and consumption chains. Without the ability to create informational feedback loops, the capacity of civil society - or of governments, for that matter-to define, publicize, and attempt to ameliorate problems created by global production processes would continually 
These information technologies remain crucial to the operation of global civil society.

Transnational Economic Structures: It is a cliche that we live in a global economy, but a profoundly important one. The worldwide flow of raw materials and products, the integration of financial markets, the growth in multi-national firms and business alliances, and the creation integrated production chains running around the world, which are driving forces in globalization, also facilitate the emergence of global civil society. The emergence of worldwide production and consumption chains has increased the scope of both transnational interdependence and the externalities associated with market activities. People living on one side of the globe are increasingly dependent on decisions risade on the other side. Decisions made on one side can have significant "external" effects on the other.

Such external effects can vary from the apparent reduction in employment in one region caused by increased employment in another, and perhaps increased profits in still another, to sea-level rises in low lying areas caused by fossil fuel burning and deforestation in other areas. One of the most striking current examples is the contamination of the arctic food chain by chemicals used as pesticides in temperate and tropical countries. ${ }^{46}$

In every case, actions taken in one governmental jurisdiction give rise to assertions of interest and grievance by people living

lose ground to globalization.

46 Innuit activist Sheila Watt-Cloutier put the case as concisely as possible: "I wonder how we have created a global situation where mothers in the Arctic worry about poisoning their children through their very life-giving breast milk, while mothers in other countries rely on these same chemicals to protect their children from disease. This situation is not only immoral, but must be deemed intolerable." Deneen L. Brown, Arctic Canada's Silent Invader: Contamination Threatens Native People's Way of Life in Fragile Region, WASHINGTON POST, May 17,2001 , at A17. Widespread agreement on this assertion is leading to the adoption of the Treaty on Persistent Organic Pollutants, one of the few recent instances in which the intergovernmental policy system shows promise of responding effectively to transnational civil society movements. 


\section{BUFFALO ENVIRONMENTAL LAW JOURNAL [Vol.10}

outside that jurisdiction. Often, they choose to pursue correctives outside the intergovernmental negotiation network through transnational civil society networks. The very interdependence created by transnational production and consumption chains gives civil society actors located in one governmental jurisdiction leverage over behavior in others. ${ }^{47}$

At the same time, the difficulty of exerting that leverage is increased by the complex nature of the economic relationships. Often, a multitude of individual firms are tied together by temporary, shifting relationships in which power and authority are dispersed along the production chain, only occasionally concentrating at the retail end. ${ }^{48}$

Reduced Roles of Governments: Although the causes and degree are subject to debate, it is quite apparent that governments have scaled back their ambitions as guarantors of public welfare in recent decades. To some extent this may be a function of the growth of the transnational economic system described above, which leap-frogs governmental jurisdictions and can punish governments that try to enforce a high degree of social accountability. Recurrent internal fiscal crises have also been important, as have "neo-liberal" political attacks on visions of protective government. In any case, the reduced ambitions of governments have made room for expanded ambitions of civil society organizations, ${ }^{49}$ and perhaps even created a demand for

$47 \quad$ E.g., Evans supra note 45; Archon Fung et al., Realizing Labor Standards: How Transparency, Competition, and Sanctions Could Improve Working Conditions Worldwide, BosTON REvIEw 26(1) (February/March 2001), available at http://bostonreview.mit.edu/BR26.1/fung.html; KECK \& SIKKINK, supra note 42.

48 Ken Conca, Consumption and Environment in a Global Economy, Global EnVironmental Politics 1(3) 53-71 (2001); Gary Gereffi, The Organization of Buyer Driven Global Commodity Chains: How U.S. Retailers Shape Overseas Production Networks, in COMMODITY CHAINS AND GLOBAL CAPITALISM (Gary Gereffi \& Miguel Korzeniewicz, eds., 1994).

49 Ronnie D. Lipschutz, Regulation for the Rest of Us? Activists, Capital, States and the Demand for Global Social Regulation (Feb. 20-24, 2001) (paper presented to the International Studies Association Conference, Chicago, available 
them. Some governments have even invited civil society organizations to take over a larger role in public governance. ${ }^{50}$

\section{$\underline{\text { Salient Characteristics }}$}

Lipschutz's path breaking article started with a relatively openended definition of global civil society: "a set of interactions among an imagined community ${ }^{51}$ to shape collective life that are not confined to the territorial and institutional spaces of States." ${ }^{952}$ Today, the website of the LSE Centre for Global Governance lists about a half dozen definitions. ${ }^{53}$ They are basically consistent with Lipschutz's, but tend to add specific features. Most of the additional features are portrayed as typical rather than necessary, ${ }^{54}$ and are described further in the next

at http://people.ucsc.edu/ rlipsch/Regulation $\% 20$ for $\% 20$ the $\% 20$ Rest \%20of\%20Us.html.)

50 Taylor, supra note 43, at 285-86. In United States domestic policy this tendency has taken a new twist with the Bush administration, which has sought to create a larger role for "faith-based organizations" in the design and delivery of domestic government programs. Rallying the Armies of Compassion, Jan. 2001, available at http://www.whitehouse.gov/news/reports/faithbased.html.

51 The term "imagined community" is used not to imply that those who think of themselves as part of the community are deceiving themselves, but rather to note that the community's existence requires people to think of themselves as members of it. See generally BENEDICT ANDERSON, IMAGINED COMMUNITIES (1983).

52 Ronnie D. Lipschutz, Restructuring World Politics: The Emergence of Global Civil Society, 21 MiLlenNIUM 389, 398 (1992).

53 LSE Centre for the Study of Global Governance, Definitions of Global Civil Society, available at http://www.lse.ac.uk/Depts/global/Yearbook /definitions.htm; Mary Kaldor, A Note on Concepts (Feb. 4-5, 2000) (paper for the Global Civil Society Almanac Brainstorming session, on file with author).

54 Id. An extensive definition is attributed to John Keane: "a complex, conflict ridden, transnational process in which, across vast distances and despite considerable time barriers, individuals, non-governmental groups and organizations, charities, lobby groups, citizen's initiatives, local independent media, corporations, [and] trade unions non-violently self-organize and interact in ever more networked ways, usually with and against state and non-state bodies, to alter, even to 'denaturalize' the power relations embedded in existing social and political orders, even to create shared understandings among actors that we live in an 
section. They include (1) self-organization, (2) semi-autonomous engagement with state agencies, (3) non-violence, (4) a frequently high degree of social contestation, and (5) networked structures.

\section{Forest Certification and Global Civil Society}

It requires little analysis to see that the above conception of global civil society is generally congruent with the world of forest certification. The primary purpose of this paper is not to offer a thoroughgoing analysis of forest certification in terms of civil society constructs, or to 'test' whether global civil society models fit forest certification better than other models. Rather, the purpose is to see how the global civil society attributes of forest certification can help us understand its policy implications and its relationship to law. Therefore, this section combines civil society scholarship with specific information about forest certification programs to create as sharp an image as possible of forest certification as a global civil society phenomenon.

\section{Actors and Organization}

Forestry has long been a sector laying claim to social trusteeship, with many western societies according foresters special status as guardians of public values. ${ }^{55}$ Forestry also has had important transnational dimensions for a long time, because much forestry culture has been transmitted around the globe from countries like Germany and (much later) the United States through professional education. In general, the forestry sector has enjoyed a high degree of professional and operational autonomy, often combined with cordial or even close relations with government. When the movement for forest certification emerged, the forestry establishment was suffering

\footnotetext{
emerging transnational, even 'global order'."

55 GREGORY A. BARTON, EMPIRE FORESTRY AND THE ORIGINS OF ENVIRONMENTALISM (forthcoming).
} 
a rapid decline in public trust. The decline was tied largely to public perceptions that forests were being harvested at unsustainable speeds, or often simply destroyed. Although North American forests were rapidly being clear-cut, deforestation of tropical forests probably brought the process to a head. The process I discussed with Professors Lyons and Mohawk regarding Brazil was being replicated with local variations in other parts of South America, Asia, and Africa, with many communities losing their land and traditional source of livelihood. ${ }^{56}$ As it grew increasingly clear that the traditional system of intergovernmental negotiation was incapable of addressing the tropical deforestation problem, there was a broad search for alternative solutions. One strategy that took off was forest certification. ${ }^{57}$

Although the history of forest certification remains contested, it is clear that the prime mover was and is the Forest Stewardship Council (FSC), founded in 1993 but planned for several years before that. Organized by a loose alliance of North American furniture makers, environmental organizations, and foundations, the FSC was designed to operate without government participation. Initially it may have been conceived as an environmentalist-industry partnership, ${ }^{58}$ but the industry role was relatively limited, and the FSC quickly evolved into a "multi-stakeholder organization" which its founding Executive Director insistently distinguishes from an NGO. ${ }^{59}$

In the eight years since its founding, the FSC has developed an elaborate, formalized stakeholder structure. Its primary governing

s6 Solon Barraclough \& Krishna B. GHIMIRE, Agricultural EXPANSION AND TROPICAL DEFORESTATION: POVERTY, INTERNATIONAL TRADE AND LAND USE (2000).

57 Jem Bendell \& David F. Murphy, Planting the Seeds of Change: Business-NGO Relations on Tropical Deforestation, in TERMS FOR ENDEARMENT: BUSINESS, NGOs AND SUSTAINABLE DEVELOPMENT (2000); Elliott, supra note 3. $58 \quad$ Bendell \& Murphy, supra note 57.

59 Tim Synott, Forest Stewardship Council, $A C$, in DEFINING A FOREST VISION: WORLD WILDLIFE FUND'S NORTH AMERICAN FORESTS FOR LIFE CONFERENCE (Kathleen Kessler et al., 1998). For historical accounts of the Forest Stewardship Council and the American Forest and Paper Association Sustainable Forestry Initiative, see Meidinger, supra note 4. 


\section{BUFFALO ENVIRONMENTAL LAW JOURNAL [Vol.10}

body is an international "general assembly" composed of three chambers-environmental, economic, and social-holding equal voting power. Each chamber is further divided into a northern and southern sub-chamber, again with equal voting power. Among other things, the general assembly is responsible for approving regional and national forest management standards developed by regional and national working groups.

Its other primary function is the accreditation of certifiers, who have the formal role of determining whether forest management enterprises meet FSC standards. I have suggested that the role of certifiers is sufficiently significant that they might be viewed as the "judges" of the FSC system. ${ }^{60}$ They certainly perform functions similar in kind and importance to those of many administrative law judges in government licensing and permitting proceedings. Membership in the FSC is voluntary, although each applicant must find at least two existing members to support its application. The FSC currently has over 450 members, approximately two-thirds of which are organizations. ${ }^{61}$

The FSC has provoked the rapid development of contending certification systems, some of which claim to have predated the FSC, but none of which did so in the form of a functioning certification program. The different programs are too complicated and variable to describe in detail here. ${ }^{62}$ It suffices to note that some, such as the

60 Errol Meidinger, Environmental Certification Programs and U.S. Environmental Law: Closer than You May Think, 31 ENVTL. L. REP. 10162, 10164 (2001).

61 Forest Stewardship Council, supra note 4.

62 See generally, Steven Bass and Markku Simula, Independent Certification/Verification of Forest Management (1999) (Background paper prepared for the World Bank/WWF Alliance Workshop, Washington, D.C., Nov. 9-10, 1999) (available at http://www.esd.worldbank.org/wwf/sim-bass.doc); Eric Hansen \& Heikki Juslin, The Status of Forest Certification In The ECE Region (1999) (paper prepared for the UN-ECE/FAO, Geneva) (available at http://www.unece.org/trade/timber/docs/certification/dp-14.pdf); Meidinger, supra note 4; Sprang, supra note 3. 
Sustainable Forestry Initiative ("SFI,") Paper Association ("AF\&PA"), are closely aligned with the forest products industry. Others, such as the Pan European Forest Certification Council ("PEFC,"), ${ }^{64}$ are also industry based, but involve a much larger government role, reflecting the traditionally close cooperation between government and the forestry industry in Europe. Depending on how one counts, there are anywhere between a halfdozen and fifteen different certification programs. ${ }^{65}$

All of the forest certification programs self-consciously operate in a larger context best described as a sprawling, largely unmapped, highly changeable, loosely networked social field in which there are several centers of activity that closely monitor each other. It includes many environmental organizations, large and small production, wholesale, and retail firms, trade associations, professional certifiers, labor unions, human rights organizations, indigenous groups, government agencies and officials, consultants, charitable organizations, citizen activists, academics, research institutes, community groups ${ }^{66}$ and undoubtedly many other types of actors. Simply categorizing all of the participants is a serious exercise in social theory. ${ }^{67}$ Relations among them involve a complex, shifting mix of

See AF \& PA 2001 Sustainable Forestry Program Overview, available at http://www.afandpa.org/forestry/sfi/SFIARSummary.2.pdf.

${ }_{64}$ See The Pan European Forest Certification Program, available at http://www.pefc.org; Sprang, supra note 3.

65 Confederation of European Paper Industries, Comparative Matrix of Forest Certification Schemes, available at http://www.cepi.org/htdocs/ pdfs/forest/puba15.pdf.

$66 \quad$ Lucy Taylor provides an extremely insightful analysis of the ways in which social movement community groups have become linked to each other as well as to transnational NGOs and funding sources in course of the global civil society movement. She also describes some of the ways in which social movement organizations have had to transform themselves to deal with the more ambiguous, less clearly good versus bad problems that have come with the democratization of many Latin American governments. Taylor, supra note 43, at 283-86.

67 E.g., Christopher Elliott \& Rudolphe Schlaepfer, Global Governance and Forest Certification: A Fast Track Process for Policy Change, in SOCIAL AND POLITICAL DIMENSIONS OF FOREST CERTIFICATION 199 (Errol Meidinger et al. Eds., 


\section{BUFFALO ENVIRONMENTAL LAW JOURNAL [Vol.10}

mutual observation, direct communication, trust, distrust, mutual adjustment, cooperation, coordination, and competition. All of the actors are clearly aware that they are part of a larger arena of forest governance and regulation. It is possible (but not clear) that shared educational experiences are also an important source of linkage. Empirical research characterizing these relationships and their history would help considerably in understanding the governance capacity of the network, as it has in the case of ozone policy networks. ${ }^{68}$

The forest certification network is linked to other civil society policy arenas, such as labor, human rights, and community development in a variety of ways, including shared members, funding sources, communications channels, and in some cases political goals. The forest certification network is also linked to specifically certification-oriented activities in other policy arenas, apparently reflecting a growing focus on organizational methods and techniques in global civil society at large. The linkages occur both through the exchange of information, ideas, and sometimes resources, ${ }^{69}$ and through participation in organizations such as the giant International Organization for Standardization (ISO), the tiny International Social Environmental Accreditation Labelling Alliance, ${ }^{70}$ and the intermediate European Organization for Conformity Assessment (EOTC).

2003); Benjamin Cashore, Response to 'Global Governance and Forest Certification: A Fast Track Process for Policy Change', in SOCIAL AND POLITICAL DIMENSIONS OF FOREST CERTIFICATION 219 (Errol Meidinger et al. Eds., 2003).

68 PENELOPE CANAN \& NANCY REICHMAN, OZONE CONNECTIONS: EXPERT NETWORKS IN GLOBAL ENVIRONMENTAL GOVERNANCE (2002).

69 Russel Dalton \& Robert Rohrschneider, Transnational Environmentalism: Do Environmental Groups Cooperate Globally? (1999)(research paper) (available at http://democ.uci.edu/democ/papers/dalton3.htm).

${ }_{70}$ ISEAL (2001), at www.isealalliance.org; Errol Meidinger, Emerging Trans-Sectoral Regulatory Structures in Global Civil Society (Jul. 4-7, 2001) (paper prepared for the Tools for Regulation Panel, Joint Annual Meetings of the Law and Society Association and the Research Committees for the Sociology of Law, Budapest Hungary) (available at http://law.buffalo.edu/ homepage/eemeid/scholarship/ISEAL.pdf). 
Large foundations also appear to provide important linkages among social and environmental labeling organizations.

\section{Substantive Values}

As noted above, civil society organizations generally promote particular values. For the most part, these tend to include social justice elements and at least some concept of the proper ordering of society. In the forest certification arena, most if not all actors embrace the value of "sustainable forest management." The question is, what constitutes sustainable forest management? There is considerable disagreement with regard to this question, as some groups promote more environmentally protective standards while others promote less protective ones, some promote community oriented standards while others promote industry oriented ones, and so on.

There are several other interesting commonalities in value, however. First, many actors in the arena behave as though they believe that a single definition of sustainable forest management is both possible and desirable. Such an assumption does not seem to characterize most other policy arenas. ${ }^{11}$ If my characterization of the forest certification network is correct, it is hard to say why that would be so. One possibility is that forestry is such a long-standing and heavily professionalized sector of civil society that many participants have been socialized into the shared assumption that there are

71 Indeed, Matthias Finger argues that one of the major shortcomings in the emerging global system in which international NGOs play an expanded role is a dissolution of shared values: "Substantive political objectives, ... such as equity, justice, and human rights, are increasingly replaced by expressive objectives, that is, basically the call of various actors for the right to express themselves". Matthias Finger, NGOs and Transformation: Beyond Social Movement Theory, in ENVIRONMENTAL NGOs IN WORLD POLITICS: LINKING THE LOCAL AND THE GLOBAL, 57 (T. Princen \& M. Finger eds., 1994). This, of course is an empirical assertion that could be empirically tested, although to my knowledge it has not been. It is also possible that international environmental NGOs have realized the need to coalesce around shared objectives, and have started to do so since Finger wrote. 


\section{BUFFALO ENVIRONMENTAL LAW JOURNAL [Vol.10}

generally correct policies and decisions. A second possibility, more grandiose but potentially shared with other civil society movements, is that humankind as a whole holds certain fundamental values that civil society organizations should promote. This might be similar to the "conscience of humanity" standard invoked in civil society debates on human rights and peace ${ }^{72}$ and possibly to natural justice ${ }^{73}$ and social contract ${ }^{74}$ analyses, which are receiving renewed attention in environmental policy circles.

A second area of convergence in certification programs is that the definitions of sustainable forest management espoused by the various actors seem to have moved in tandem with each other over time. In broad outline, they have moved from a "sustained yield" or "cropping" conception of forestry (in which the goal was to provide a constant and predictable stream of outputs-usually timber), to an ecologically-oriented one (in which the goal was to preserve the

72 E.g., Richard Falk, The Nuclear Weapons Advisory Opinion and the New Jurisprudence of Global Civil Society, 7 TRANSNAT'L L. \& CONTEMP. PROBS. 333, 349 (1997); E. BARKAN, THE GUILT OF NATIONS: RESTITUTION AND NEGOTIATING HISTORICAL INJUSTICES (2000). Interestingly and importantly, substantial evidence from opinion polls indicates that there is essentially global agreement on the necessity of protecting the environment. The level of support for environmental protection, including the willingness to accept added costs, does not seem to vary significantly among affluent and less affluent nations. RILEY DUNLAP ET AL., HEALTH OF THE PLANET SURVEY (1993); Dalton \& Rohrschneider, supra note 69; There is a related idea in the traditional corpus of international law, which holds that nation states are under an inherent obligation to the international community (erga omnes) not to engage in aggression, genocide, slavery, or racial discrimination-and possibly to safeguard the earth's ecological balance. ALEXANDRE KISS \& DINAH SHELTON, INTERNATIONAL ENVIRONMENTAL LAW 25 (2000).

${ }_{73} \quad$ Richard D. Schwartz, Natural Law (Jul. 7, 2001) (paper presented to the Joint Annual Meetings of the Law \& Society Association and the Research Committee for the Sociology of Law, Budapest, Hungary) (on file with author).

${ }_{74}$ Joseph F.C. Dimento, Process, Norms, Compliance, and International Environmental Law (Jul. 4-7, 2001) (paper presented to the Joint Annual Meetings of the Law and Society Association and Research Committee for the Sociology of Law, Budapest, Hungary) (copy on file with author). 
structure, function, and composition of forest ecosystems), to one explicitly linking the viability of forests to that of local communities and other social groups that depend on them. This pattern suggests that there is a broad value dialogue in the certification arena. Indeed, much academic work has been devoted to comparisons between the standards of various certification programs, evidently based on the assumption that they can be evaluated according to a common metric. ${ }^{75}$ Moreover, some researchers argue that certification systems have a built in tendency to compete with each other, thereby "ratcheting up" definitions of best practice. ${ }^{76}$

Third, the values being promoted are not limited to matters of trees and ecosystems, but also, as in other policy arenas, include visions of the "good society." The guiding principles and formal organization of the Forest Stewardship Council, for example, express a commitment to protecting the viability of forest communities and the health and employment of forest workers. They can be understood as one expression of the vision of "sustainable development"-linking environmental, economic, and social viability - that has grown out of the global discussion of environment and society in recent decades. Conversely, the standards of the AF\&PA's SFI program do not include comparable responsibilities to communities and workers. Rather, they stress the autonomy and economic viability of individual firms, implicitly asserting that the most sustainable system will be the one that retains maximum autonomy for business. The ISO, similarly and more emphatically, makes the firm the center of environmental policy making. ${ }^{77}$ In sum, each certification program encodes and promotes a vision of proper social ordering, and thus seeks to change or reinforce patterns of authority well beyond forestry.

7s E.g., CEPI, supra note 65 ; Ewald Rametsteiner, Sustainable Forest Management Certification-Frame Conditions, System Designs and Impact Assessment (2000) (paper prepared for Ministerial Conference on the Protection of Forests in Europe, Liasion Unit Vienna, Vienna, Austria) (on file with author).

$76 \quad$ Fung et al., supra note 47.

$77 \quad$ See generally Meidinger, supra note 4. 


\section{BUFFALO ENVIRONMENTAL LAW JOURNAL [Vol.10}

\section{Methods}

Kaldor argues that the modern civil society movement is characterized as much by particular methods of organization and policy making, as by substantive ideals. ${ }^{78}$ This certainly seems to be true for forest certification programs, and probably for a much larger subset of contemporary civil society movements. Of course, the central idea of forest certification is itself an organizational technique involving the application of publicly announced standards to individual forest enterprises by social actors with defined responsibilities. Beyond this, however, the certification movement might well be characterized as an agglomeration of linked methods and techniques that are relied upon to some extent by all forest certification programs.

The first is stakeholder oriented policy making. Individual certification programs vary greatly in the amount and locus of

$78 \quad$ Kaldor, supra note 38, at 475-76. With regard to Eastern Europe, Kaldor cites especially a reliance on (1) self-organization, (2) non-violent protest, (3) dialogue, and (4) compromise. While these methods also seem to characterize forest certification, their importance as markers may not be as great as they are in Kaldor's implicit contrast to state based processes. Defining self-organization in the conventional sense as phenomena which appear to determine their own form and processes, one can look around forest certification arena and describe much of it as self-organized. Humberto Maturana \& Francisco Varella, Autopoiesis and Cognition: The Realization of the Living, in 42 BOSTON STUDIES IN THE PHILOSOPHY OF SCIENCE (1980). The Forest Stewardship Council, after all, simply started itself up and declared itself to be in the business of accrediting certifiers and approving certification standards, and did so according to procedures set by itself. People and organizations then proceeded to join and otherwise participate in FSC processes. Similarly, the PanEuropean Forest Certification Council and possibly even the American Forest \&Paper Association's Sustainable Forestry Initiative could be described as self-organized. Yet the programs, particularly the PEFC and SFI, were built in considerable part by pre-existing organizations and interests and based on long-standing views of sustainable forest management. So the question arises, self-organized in relation to what? Depending on one's perspective, it is possible to portray forest certification either as primarily self-organized or as a natural outgrowth of long-term processes. The same kind of critique applies to the methods of non-violence, dialogue, and compromise. All are common attributes, but only part of the story. 
participation, but all require it somewhere and to some extent. The FSC system is by far the most elaborate, with the three-chamber, north-south structure discussed above, along with considerable public input requirements in the regional standard setting processes and individual certifications. Yet, despite its far reaching implementation of stakeholder models, there are places where the FSC system remains strikingly non-participatory and non-transparent, particularly at the level of the individual certification. ${ }^{79}$ The programmatic vision, however, is broader and seems to be moving toward realization.

On the other end of the spectrum is the $\mathrm{ISO}^{80}$ family of processes, including the AF\&PA Sustainable Forestry Initiative, ${ }^{81}$ all of which require some public comment process, and some of which have occasionally utilized focus groups, but little more. Even in these programs, however, the boundaries are becoming more permeable. Actors outside firms are increasingly likely to be conceptualized as stakeholders. And it usually seems possible, if often difficult and costly, for interested parties to gain at least some input to decision processes. The growing use of stakeholder processes may reflect larger "transnational democratic tendencies" that Falk describes as a "feature of the international legal order at the end of the 20th century". ${ }^{82}$ But this assessment remains a bit optimistic at the moment, and much remains to be seen regarding the role of stakeholder processes in certification programs.

A second method common to forest certification programs is a heavy reliance on science and professional expertise, both for defining standards and for legitimating them. The field is at least as powerfully shaped by the professional views of foresters and ecologists as are state-based regulatory systems-perhaps more so. A

See Meidinger, supra note 4, at 160, 179; Eckhard Rehbinder, Ecological Contracts: Agreements Between Polluters and Local Communities, in ENVIRONMENTAL LAW AND ECOLOGICAL RESPONSIBILITY (Gunther Teubner, et al. eds., 2001).

${ }^{80}$ ISO (2001), at www.ico.ch.

81 AF \& PA, supra note 63.

$82 \quad$ Falk, supra note 72, at 334. 
large part of the debate about certification standards is framed in scientific terms. For example, the debates about clear felling and chemical use focus heavily on the effects they are predicted to have on forests. Scientists assert a special relationship with the future in making arguments about alternative policies, ${ }^{83}$ and most of the key actors in the field are scientifically trained. At the same time, there seems to be a widely held sense that science cannot fully resolve the questions at stake, and that they will necessarily involve value judgments and the balancing of interests.

It is perhaps not surprising, therefore, that juxtaposed with science and expertise is the third method common to certification programs: use of public relations and marketing techniques. These have included shaming mechanisms such as public protests, picket lines, mock "chain saw massacres" outside retail stores, announcements over store intercoms extolling the store's record of destroying rain forests, and so on. ${ }^{84}$ They have also included standard marketing techniques such as focus group testing, mass media advertisement ${ }^{85}$ and trade fairs, as well as public commendations, the most important of which is the eco-label itself. The eco-label is intended to signify "good," "responsible, "sustainable," or sometimes even "exemplary" forest management, depending on the program. It is used to mark a product for the public as having environmentally and sometimes socially appropriate origins, a 'pedigree,' as it were. Thus, a piece of certified mahogany can be distinguished from an apparently identical piece that might have been produced in violation of a sustainable management plan, environmental laws, native land rights, or worker

83

Inger-Johanne Sand, Drawing Upon the Future: Socio-Legal Theories, Risk, and the Application of Specialised Knowledge (2001) (ARENA working paper, University of Oslo, Norway) (on file with author)

${ }_{84} \quad$ Bendell \& Murphy, supra note 57; Jim Carlton, Against the Grain: How Home Depot and Activists Joined to Cut Logging Abuse, WALL STREET JOURNAL, Sept. 26, 2000, at A12.

${ }_{85}$ The FSC, for example, has placed advertisements featuring Pierce Brosnan and Olivia Newton-John in People and Playboy magazines. The AF\&PA is planning a major $\$ 25$ million ad campaign as this is written. Kim \& Carlton, supra note 28. 
safety laws, depending on the certification program. The purpose of the label is to enhance access to consumers by sellers of properly produced products while reducing access by sellers of improperly produced ones. Similar labeling strategies have appeared in many other sectors, including foods, textiles, and a whole set of "fair trade" products for which primary producers are certified to have been paid a living wage and accorded locally appropriate labor standards. ${ }^{86}$ Labels are becoming so important that the ISO and EU have devoted major efforts to developing guidelines for them, ${ }^{87}$ and at least one separate alliance of environmental and social labeling organizations has emerged. ${ }^{88}$

A fourth important organizational methodology is the use of environmental management systems (EMSs) to pursue the objectives of certification programs. The central idea is that each forest management organization should develop a system for considering its environmental impacts, planning which ones to reduce and how, implementing the plan, monitoring its success, and making adjustments over time.$^{89}$ These processes must be formally provided for by the organization, and particular individuals assigned responsibility for carrying them out. The

${ }^{86}$ See generally Janelle Diller, A Social Conscience in the Global Marketplace? Labour Dimensions of Codes of Conduct, Social Labelling, and Investor Initiatives, 138 INT'L LAB. REV. 99, 99-129 (1999).

87 ISO, supra note 80; European Organization for Conformity Assessment (2001), at http://www.eotc.be.

${ }_{88}$ ISEAL, supra note 70.

89 Ironically, as noted in the section on adaptability, environmental management systems seem to constitute the main opportunity for implementing adaptive management in certification programs. The basic idea of adaptive management is that social organizations should consider their goals, plan how to meet them, implement their plans, monitor their performance, reconsider their plans, and make appropriate changes. KAI N. LEE, COMPASS AND GYROSCOPE: INTEGRATING SCIENCE AND POLITICS FOR THE ENVIRONMENT (1993). At the broader programmatic level, certification systems seem not to have established mechanisms for adaptive management. Although it could turn out that the larger debate about sustainable forest management will play part of that role, at present certification systems have not made plans for monitoring and revising their own performance. 


\section{BUFFALO ENVIRONMENTAL LAW JOURNAL [Vol.10}

FSC has placed relatively low emphasis on management systems to date, evidently out of a desire not to make it too difficult for small, indigenous, or community based enterprises to attain certification. Many EMS requirements include a commitment to "continuous improvement" (although there is contention about what must be improved-the management system or organizational performance) and to compliance with applicable laws. Thus, the basic idea of the EMS is to harness the organizational dynamics of the forest management enterprise to the objectives of the certification program.

Fifth, certification programs use formal principles and law-like codes to define their standards and structure their operations. These are exemplified by the FSC's hierarchical system of principles and criteria, indicators, and national standards, as well as its many statutes, procedural requirements, and the like. ${ }^{90}$ For example, FSC Principle 6 provides as follows:

Forest management shall conserve biological diversity and its associated values, water resources, soils, and unique and fragile ecosystems and landscapes, and, by so doing, maintain the ecological functions and the integrity of the forest. ${ }^{91}$

That principle is then given concrete meaning in regional standards and criteria, such as the following draft criterion from the northeastern region of the US:

Management systems shall promote the development and adoption of environmentally friendly non-chemical methods of pest management and strive to avoid the use of chemical pesticides. World Health Organization Type IA and IB and chlorinated hydrocarbon pesticides; pesticides that are persistent, toxic or whose derivatives remain biologically active and accumulate in the food chain beyond their intended use; as well as any pesticides banned by international agreement, shall be prohibited. If chemicals are used, proper equipment and training shall be provided to minimize health and environmental risks.

Forest Stewardship Council, supra note 4. 
Aside from being stricter, this criterion is effectively indistinguishable from the regulations promulgated by government environmental regulatory agencies, and there are over a hundred other such criteria for each region. Thus, the reliance on legal forms for managing the FSC program is considerable. Although other forest certification programs tend to be less formally elaborate and specific, all of them appear to be moving in the direction of increased codification. The codes cover the operation of both the certification program and the certified organizations, defining a broad range of roles and responsibilities for the actors. Again, the use of principles and codes is being replicated in many areas of civil society, including human rights, labor standards, and fair trade. There are countless organizations involved in developing codes and implementation systems and in assessing compliance. ${ }^{92}$

Finally, forest certification programs increasingly rely on what they define as 'independent. third-party certifiers' to assure compliance with their principles, criteria, and standards. Different programs have different ways of accrediting certifiers and defining their independence. Some do not require third-party certification..$^{93}$ But they all are moving toward the use of third party certifiers, and the underlying principle seems to be gaining ground in the forestry arena. As with the other methods described above, the use of independent

92 For a brief description of the certification organizations involved in the International Social and Environmental Labelling Alliance, see Errol Meidinger, Emerging Trans-Sectoral Regulatory Structures in Global Civil Society: The Case of ISEAL (the International Social and Environmental Accreditation and Labelling Alliance) (2001) (paper prepared for the Tools for Regulation Panel, Joint Annual Meetings of the Law and Society Association and the Research Committee for the Sociology of Law, July 4-7, Budapest, Hungary) available at http://law.buffalo.edu /homepage/eemeid/scholarship/lSEAL.pdf.

93 Certification is commonly classified as either first-party (selfcertification), second-party (typically a trade association or customer), third-party (a separate certification organization) and even fourth-party (a government or multilateral agency). Gary Gereffi et al., The NGO-Industrial Complex, FOREIGN POLICY, July-Aug. 2001, available at http://www.foreignpolicy.com/ issue julyaug_2001/gereffi.html. 
certifiers or auditors seems to be gaining ground in other civil society sectors as well.

\section{Role in Global Society}

The overall picture that emerges is one of forest certification in particular and civil society in general replicating and expanding the kind of regulation often performed by governments, and extending it to a transnational level. In doing this, civil society organizations do not focus on lobbying governmental or inter-governmental agencies; rather, they create their own systems to operate in parallel with governmental ones. They often take a primary role in defining problems, conceptualizing solutions, and shaping public culture, consistent with Finger's portrayal of international environmental NGOs generally, ${ }^{94}$ but also go on to establish implementation structures for their programs. ${ }^{95}$ Of course, the civil society regulatory system's coverage is spotty and its efficacy untested, but the basic pattern and impulse are evident. The key reasons for the growth of civil society regulation are described in the "facilitating elements" section above: global information technology, global economic integration, and reduced government capacity.

Governments have a particularly difficult time establishing regulation at the global level because there are a huge number of factors that can derail negotiations when each state must consent to be bound and when there are many issues of contention among the states.

\footnotetext{
$94 \quad$ Finger, supra note 71 , at 60.

95 Meidinger, supra note 4; Erika N. Sasser, The Certification Solution: NGO Promotion of Private, Voluntary Self-Regulation (May 29-31, 2002) (paper prepared for the 74th Annual Meeting of the Canadian Political Science Association, Toronto).
} 
Transnational certification programs arguably have a better opportunity because they focus on a narrower range of issues and have fewer veto points. ${ }^{96}$

Still, the situation is more complicated than forest certification displacing government regulation of transnational problems for efficiency reasons. First, certification programs appear to have stimulated increased activity and innovation by government agencies as well, engaging them in sustainable forest management debates and sometimes in mounting their own certification programs. Second, a growing number of governments are subjecting the forests they manage to certification, evidently using the process to improve either the quality or the legitimacy of their management. Thus, certification programs can be seen as regulating both businesses and governments. ${ }^{97}$

Third, certification programs do not necessarily displace government regulatory programs; rather, they tend to incorporate them and extend them. All certification programs require efforts to comply with applicable government made laws. At least in the near term, therefore, certification programs can be seen as likely to strengthen governmental regulatory programs where they exist, and possibly to lay the groundwork for them where they do not. ${ }^{98}$ This raises the possibility that forest certification should not be seen so much as a corrective or a challenge to governmental legal systems, but more as

Conversely, Picciotto suggests that they may be at a relative disadvantage because they not have the option of achieving compromise solutions based on trade-offs. Sol Picciotto, Networks in International Economic Integration: Fragmented States and the Dilemmas of Neo-Liberalism, 17 INT'L L.\& BUS. 1014, 1045 (1997).

97 For a conceptual analysis of the various ways in which governmental, business, and non-governmental organizations regulate one another, see Colin Scott, Analysing Regulatory Space: Fragmented Resources and Institutional Design, 2001 PuB. L. 329, 329-53 (2001).

98 This hypothesis raises a problem that should be mentioned now, although it cannot be meaningfully addressed in this paper: which governmental regulatory systems will certification further? Not all of them are the same. Does global forest certification privilege particular concepts of proper forest management, presumptively North American and European ones? 


\section{BUFFALO ENVIRONMENTAL LAW JOURNAL [Vol.10}

an extension and amplification of them. To consider this possibility further, it is necessary to lay some conceptual foundations regarding the role of law in civil society.

\section{Domestic}

\section{Law and Civil Society}

The relationship of law to civil society has usually been either ambiguous or contested. The Greeks and Romans took the rule of law to be essential to civil society, but had a multitude of theories about the source of law. During the feudal period, the guilds and other urban corporate bodies that gave rise to civil society played a large role in making and enforcing rules. As the nation states solidified their authority and created separate forums for authoritative law making, they generally endorsed and adopted guild and community made rules, but also gradually revised them to provide interregional consistency, pursue their own goals, and accommodate new conditions. ${ }^{99}$ Concurrently, the nation states asserted a monopoly on the authority to make binding laws. Legal theorists assisted that effort by developing a supporting rationale, systematizing law at the level of the nation state (particularly in civil law countries), and establishing elite 'national' law schools.

Since the late $18^{\text {th }}$ century, the assumption that law necessarily emanates from a sovereign state has become deeply embedded in both Civil and Anglo-American legal thought. Accordingly, it is not surprising that modern commentators often take as given that the law of civil society is made by nation states, and that nation states must be urged by civil society actors-petitioned by them-to make laws supporting civil society in the first place and to implement civil society agendas in the second. ${ }^{100}$

In practice, however, the situation has always been more

\footnotetext{
99 Gianfranco Poggi, The Development of THE Modern State: A SOCIOLOGICAL INTRODUCTION 78-79 (1978).

100 E.g., Mertus, supra note 27, at 1338-339; Etzioni, supra note 31 at 356-57.
} 
complex. Continental legal scholars such as Ehrlich ${ }^{101}$ and Heller ${ }^{102}$ pointed out that law must take on meaning from the context in which it is implemented; people give meaning to legal terms by the inevitably variable ways in which they live and organize themselves to implement them. Heller explained this difficult argument as follows: "The very same general court structure proclaimed by Josef II would lead in Austria to a written and mediated court procedure, but in the Netherlands to an oral and immediate one". ${ }^{103}$ Thus, civil society necessarily has a role in 'making' law, even when the official source of law is the state. Weber took the argument a major step further by arguing that law means little unless it is accorded legitimacy by society, and that it must therefore be made with the goal of legitimacy in mind. ${ }^{104}$ Thus again, actors outside the state necessarily shape the law given to them by the state because the state must tailor it to gain their acquiescence.

Although Anglo American systems never adopted the positivist view as completely as the civil law systems, their courts, legislatures and administrative agencies came over time to be seen as the exclusive sources of law. The American legal realists of the $1920 \mathrm{~s}-1950 \mathrm{~s}$, however, countered by arguing that much law was in fact made outside government bodies. For example, a contract between employer and employee was legally binding and enforceable by government agencies without significant government input as to its terms. The parties therefore could be seen as defining the substantive content of law, and hence as exercising delegated state power. Not

101 E. Ehrlich, Fundamental Principles of the Sociology of LAW (Arno Press 1975) (1913).

102 H. HELLER, STAATSLEHRE Part 111 (1963), reprinted in H. Heller, The Nature and Structure of the State, 18 CARDOZO L. REV 1139, 1139-1215 (David Dyzenhaus trans., 1996).

103 Id. at 1191 . A post-modernist might argue along strikingly similar lines that actors give meaning to the text in enacting it, and therefore are themselves authors of the law.

104 MAX WEBER, ECONOMY AND SOCIETY: AN OUTLINE OF INTERPRETIVE SOCIOLOGY (Guenther Roth \& Claus Wittich eds., Ephraim Fischoff et al. trans. 1978) (1922). 
only that, but the terms of the contract would very likely reflect preexisting social or economic relationships in society. ${ }^{105}$ Thus in reality, the authors of the law would not be the individual contractors so much as the system of social relationships in which they operated-in effect civil society in many cases.

Karl Llewellyn and others extended this insight by arguing that judges and legislators should adjudicate and legislate based on empirical information about the social practices to which the law applies. A commercial code, for example, should be based on the practice and context of real-world commercial transactions, rather than on abstract principles. The same would be true of laws governing non profit organizations such as unions, religious organizations, and so on-thus allowing civil society to "author" general rules of law. In addition, particular legal documents should be interpreted in terms of the "usage in trade" providing the context for the transaction to which they apply, which the parties could be presumed to have presupposed in their bargaining. ${ }^{106}$ In sum, continental and Anglo-American legal scholars laid strong conceptual foundations for a revitalized understanding of civil society's role of in law making during the first half of the $20^{\text {th }}$ century.

One might expect that the rapid growth of the empirical social sciences in the second half of the $20^{\text {th }}$ century would stimulate much further progress in clarifying the relationship between civil society and law. That does not seem to have been the case, however. Although the reasons go well beyond the scope of this paper, two are relevant to this analysis. First, most members of what came to be called the "law and society movement" have been unwilling to focus on defining which social phenomena count as law and which do not. This posture seems to reflect a sense that pursuing such a question is likely to lead into an infinite regress of formalist jurisprudential arguments that simply recapitulate their premises. Moreover, many law and society scholars

105 Robert Hale, Law Making by Unofficial Minorities, 20 COLUM. L. REV. 451,451-72 (1920).

106 KARL LLEẈELYN, THE COMMON LAW TRADITION: DECIDING APPEALS (1960). 
seem to have assumed that what counts as law is an empirical question, although this assumption is conceptually problematic and accepted methods for addressing it have never been developed.

Second, law and society researchers have typically drawn upon established social science disciplines and sought to explain legal phenomena in terms of variables central to those disciplines. To a great extent this has meant viewing the work of courts, administrative agencies, and legislatures as products of economic interests, political power, social class, cognitive assumptions, and the like. Efforts to bring these variables together in a "legal system" conception might well have included a component with civil society as a law-maker, but by and large they have not. ${ }^{107} \mathrm{Law}$ and society scholars nudged toward that possibility by developing the concepts of formal and informal legal systems ${ }^{108}$ and law-in-the-books versus law-in-action. ${ }^{109}$ But they pulled back from the potential implications of these ideas with regard to modern societies. On one hand, informal law making was seen largely as a phenomenon of "traditional" rather than "modern" societies, and often as a matter of "normative," rather than truly legal ordering. Thus it is not surprising that today a separate "law and norms" movement has emerged, which blithely assumes that norms are distinct from law, and then expresses collective wonder at the importance of norms in ordering social life. ${ }^{10}$

Law-in-action studies, on the other hand, have concentrated almost entirely on the way law is made and applied by governmental bodies. Thus, law and society scholars have focused on the outputs of national and local governments, judges and legislators. Whether the research is on disputing, the legal profession, legal agencies, or even

107 E.g., LAWRENCE FRIEDMAN, THE LEGAL SySTEM: A SOCIAL SCIENCE PERSPECTIVE chs. 1 \& 6 (1978).

108 E.g., Richard D. Schwartz, Social Factors in the Development of Legal Control: A Case Study of Two Israeli Settlements, 63 YALE L. J. 471, 471-91 (1954).

109 Richard Abel, Law in the Books and Books about Law, 26 STAN. L. REV. $175,175-228$ (1973).

110 E.g., ERIC A. POSNER, LAW AND SOCIAL NORMS (2000). 
legal theory, most research seen as central to the field"I has as its endpoint and taken-for-granted analytical filter government legal institutions, thus neglecting the potential law making operations of civil society institutions.

Still, there exist several strands of socio-legal research that have focused to some extent on civil society relationships. Perhaps the best known is research on how people understand and incorporate (or ignore) law in their everyday lives. ${ }^{112}$ For the most part, however, work in this tradition has not critiqued the assumption that law is made up of the rules and acts of the governmental agencies. Rather, it has focused on the distance between government and civil society, and the nature of interactions between them.

A second school of thought has explicitly rejected the assumption that law is necessarily associated with government agencies, and sought instead to bring into the ambit of law the full set of social institutions that define and enforce social rights and duties. In his study of industrial relations, for example, Philip Selznick, ${ }^{113}$ built on the post-realist work of Lon Fuller ${ }^{114}$ and H.L.A. Hart ${ }^{115}$ to describe important law making processes in non-governmental organizations such as arbitration associations and universities. While widely admired, however, this and related work ${ }^{116}$ seems to have had little effective impact on the state-centric understanding of law held

III See generally Frank Munger, Mapping Law and Society, in CrOSSING BOUNDARIES: TRADITIONS AND TRANSFORMATIONS IN LAW AND SOCIETY RESEARCH (1997).

112 E.g., Carol J. Greenhouse et al., LaW and Community in ThreE AMERICAN TOWNS (1994); LAW IN EVERYDAY LIFE (Austin Sarat \& Thomas R. Kearns eds., 1993).

113 PhILIP SELZNICK, LAW, SOCIETY, AND INDUSTRIAL JUSTICE (1969).

114 LON L. FULLER, THE MORALITY OF LAW (1964).

115 H.L.A. Hart, Law as the Union of Primary and Secondary Rules, in THE CONCEPT OF LAW Ch. V (1964).

116 E.g., Marc Galanter, Justice in Many Rooms: Courts, Private Ordering, and Indigenous Law, 19 J. OF LEGAL PLURALISM 1, 1-47 (1981). 
by most empirical researchers, legal scholars and practitioners. ${ }^{117}$ The same seems to be true of "legal system" approaches developed in the past few decades by German theorists such as Luhmann ${ }^{118}$ and Teubner. ${ }^{119}$ Although they have sought to locate the essence of law in the capacity of social institutions to declare certain types of acts acceptable or unacceptable, their impacts on scholarship and practice to date appear to be very limited..$^{120}$ It is possible, however, that the currently marginal schools of thought represented by Selznick and Luhmann will receive a strong push toward the center of legal scholarship by the recent and rapid development of global law making institutions that are not reducible to government agencies.

\section{Global}

With the 1648 Treaty of Westphalia, the global legal arena officially became the "inter-national" legal arena-meaning that it was constituted solely by, for, and of nation states. Enacting a vision worked out by Hugo Grotius ${ }^{121}$ and others in the preceding decades,

117 Ironically, one of the major studies of non-governmental regulation, RosS

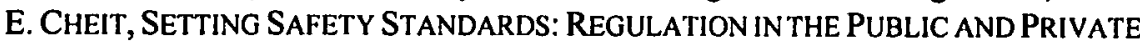
SECTORS (1990) (originally prepared as a Berkeley doctoral dissertation, does not build on Selznick's insights).

118 NikLas LUHMANN, A SOCIOlOGiCAL THEORY OF LAW (Martin Albrow ed., Elizabeth King \& Martin Albrow trans. 1985); Klaus A. Ziegert, The Thick Description of Law: An Introduction to Niklas Luhmann's Theory of Operatively Closed Systems, in LAW AND SOCIAL THEORY (Max Travers \& Reza Banakar, eds., forthcoming).

119 Gunther Teubner, Breaking Frames: The Global Interplay of Legal and Social Systems, 45 AM. J. CoMP. L. 149, 149-67 (1997).

120 For an early effort to apply the perspective of Luhmann and Teubner to forest certification, see James Lawson \& Benjamin Cashore, Reasearch Note: The Application of the Theory of Social Autopoiesis to the Problem of Non-State Sanctioned, Market-Driven (NSMD) Governance, (n.d.) (on file with author). For a particularly clear and careful exposition of Luhmannian legal theory, see Ziegert, supra note 118.

121 Hugo Grotius, THE LAW of WAR AND PEACE (Francis Kelsey, with Arthur Boak trans., 1925) (1625). 
the nation states constituted themselves as independent, equal, and exclusive legal actors in the international arena. Each was free to make laws governing its citizens, lands, and other assets. Any law applicable across or beyond the jurisdictions of nation states had to be made by the nation states affected, either by treaty or by some other mutually recognized process. Any law imposing an obligation on a state had to rest on a formal expression of consent by that state. ${ }^{122}$

The Westphalian legal system has long been under pressure for reasons too numerous to discuss here. The factors driving globalization described above are among the most important. International trade in particular has created huge challenges for state-based conceptions of law. The drive to simplify and promote trade has been an important factor in the rise of the European community, and its establishment of institutions that are not explicable merely as agreements among states. ${ }^{123}$

International trade also has driven the growth of legal institutions more self-consciously distinct from states. Since an interstate transaction crosses jurisdictions, it could conceivably be governed by the law of either jurisdiction, and international traders have gone to enormous lengths to attempt to choose the law applicable to their transactions. In general, each trader is likely to have an aversion to submitting to the legal system of the other trader. It did not take traders long to realize that there might be advantages in being governed by law from still other jurisdictions, or even in making their own law and using arbitrators to enforce it, and they took steps to do both. Gradually a distinctive set of rules and institutions for dealing with transnational commercial transactions has arisen-lex mercatoria, the "law merchant."

Although a tremendous amount of ink has been spilled debating the status and content of lex mercatoria, the present discussion can be limited to two basic points. First, a large number of problems regarding

${ }^{122} \quad$ Falk, supra note 72, at 337. 30-Dec. 1, 2001) (background paper for the Conference on Constitutionalism and Transnational Governance, Florence). 
international commercial transactions are in fact settled through the lex mercatoria system. ${ }^{124}$ Second, the system is not reducible to the law of states or to laws made by combinations of states. This is so even though many state legal systems are committed by treaty to enforce the judgments of non-state lex mercatoria arbitration panels. ${ }^{125}$ The obvious next question is whether lex mercatoria should be treated as law or as something else. This is a question which I may yet write about in detail, but not here. For now it suffices to say that the benefits of holding off with thinking about phenomena such as lex mercatoria as law until all of the traditional elements (e.g., a widely recognized coercive mechanism) are clearly present are far outweighed by the costs. To hold back, or to argue about definitions, is to forego the opportunity to carry out research and analysis on non-governmental law making while it is happening - a high cost indeed. Moreover, it is to deprive civil society institution building processes such as forest certification of the full experience and scrutiny of legal and socio-legal research, a problem regardless of whether one is a supporter or a critic. ${ }^{126}$ For now, therefore, I think it appropriate to treat Teubner's bold statement as probably accurate and work form that basis.

[G]lobalization of law creates a multitude of de-centered lawmaking processes in various sectors of civil society, independently of nation-states. Technical standardization, professional rule production, human rights, intra-organizational regulation in multinational enterprises, contracting, arbitration and other institutions of lex mercatoria are forms of rule making by

\footnotetext{
124 E.g., Y. DEZALAY \& B.G. GARTH, DEALING IN VIRTUE: INTERNATIONAL COMMERCIAL ARBITRATION ANDTHE CONSTRUCTION OF A TRANSNATIONAL LEGAL ORDER (1996).

125 Under the New York Convention of 1958 over 120 countries have committed to enforce arbitral awards where such awards are based on written contracts to subject commercial disputes to arbitration and to abide by the decisions. Philip J. McConaughay, The Scope of Autonomy in International Contracts and Its Relation to Economic Regulation and Development, 39 COLUM. J. TRANSNAT'L L. 595, 611 (2001).

$126 \quad$ Peter J. Spiro, New Global Potentates: Nongovernmental Organizations and the 'Unregulated' Marketplace, 18 CARDOZO L. REV. 957, 957-69 (1996).
} 
'private governments' which have appeared on a massive global scale. They claim worldwide validity independently of the law of nation-states and in relative distance to the rules of international public law. They have come into existence not by formal acts of nation-states but by strange paradoxical acts of self-validation. ${ }^{127}$

\section{Basic Conceptual Perspectives}

Before proceeding, it is appropriate to note that there seem to be two basic approaches to the decision to treat lex mercatoria and other forms of non-governmental regulation as law, which can be characterized loosely as internal and external. Internal perspectives focus on the nature of the system that produces the phenomenon at issue. There are several variants. One focuses on the institutions involved in the system. The traditional legal positivist perspective, for example, generally requires that for law to exist an agency of a nation state must formulate an order that it is prepared to enforce with coercion. ${ }^{128}$ The focus on the nation state is limited to a particular historical period, however, and there is no good reason to believe that law did not exist prior to the nation state. Thus, there is no inherent reason the list of relevant institutional sources cannot be enlarged. One could conceivably include some or many of the "civil society" organizations described above in the legal system.

A second variant of the internalist perspective focuses on characteristic functioning and products of the system. This is the strategy of Luhmann ${ }^{129}$ and Teubner, ${ }^{130}$ which focuses on social communication processes that produce "binary coding"-e.g, legal/ illegal. Since the judgment could as well be sustainable/unsustainable, it seems plausible to treat forest certification as a form of law making. The only limitation in principle is the occasional timidity of the

127 Gunther Teubner, 'Global Bukowina': Legal Pluralism in the World Society, in GLOBAL LAW WITHOUT A STATE (1997).

128 JohN AUSTIN, THE PROVINCE OF JURISPRUDENCE DETERMINED (Humanities Press 1965) (1832).

$129 \quad$ LUHMANN, supra note 118; Ziegert, supra note 118.

$130 \quad$ Tuebner, supra note 119. 
certification systems in holding back from using strong and definite labels.

The externalist approach to defining law looks at how it is received and used in the larger society. This is the approach suggested by Weber's concept of legitimacy. Falk and Strauss build upon it by emphasizing a public expectation that people will conform to a rule, and the "pull toward compliance" exerted by the rule. ${ }^{131}$ It is the force of public justice referred to by Professors Mohawk and Lyons in the mid-1980s discussion described above. Legitimacy is a difficult criterion to apply in practice, since different people could disagree on whether such an expectation of and pull toward compliance exist in a particular cases, but it refers to a very important aspect of law which it would be hard to justify ignoring, as is discussed further in the concluding section of this paper.

A second externalist strategy is to look at how society uses organizations in a given social field to make and enforce rules. This is the method used by Dezalay and Garth in their study of the growth of an arbitration system for resolving transnational commercial disputes. ${ }^{132}$ Their distinctive contribution is to describe in detail how transnational enterprises use dispute resolution services and how potential arbitrators and arbitration alliances build institutions to compete for business in the field. In the course of that competition they shape the overall transnational commercial arbitration system in ways that suit their interests and those of the commercial transactions system. It seems likely that a similar approach could be used to describe the field of forest certification, wherein programs compete for influence and legitimacy, and in the course of that competition

131 Falk \& Strauss, supra note 44, at 207 following the argument sketched out in THOMAS FranCK, THE POWER OF LEGITIMACY AMONG NATIONS (1990).

132 DEZALAY \& GARTH, supra note 124; Yves Dezalay \& Bryant Garth, Merchants of Law as Moral Entrepreneurs: Constructing International Justice from the Competition for Transnational Business Disputes, 29 L. \& SOC'Y REV. 27, 27-54 (1995). Examples of other scholars following this general approach include Spiro, supra note 126, PAUL WAPNER, ENVIRONMENTAL ACTIVISM AND World Civic Politics (1996), and John Braithwaite \& PETER Drahos, GLOBAL BUSINESS REgULATION (2000). 


\section{BUFFALO ENVIRONMENTAL LAW JOURNAL [Vol.10}

shape the overall law and policy of forest certification. ${ }^{133}$

In sum, if one takes the criteria discussed above-institutional rule-making and adjudication mechanisms, public legitimacy, and social usage - there is a good, although not incontrovertible case for treating forest certification as a form of law making, specifically of environmental law making. The next question is what this choice gains us. Before addressing it a brief overview of environmental law will be helpful.

\section{Environmental Law and Civil Society}

\section{Domestic}

If forest certification is a kind of law making, it is probably a kind of environmental law making. To see how it fits and potentially changes the structure of environmental law, it is necessary to have a working overview of the field. Although I cannot possibly survey environmental law around the globe, this section begins by providing an overview of environmental law development in the AngloAmerican system.

Environmental law can be generally defined as the law governing the relationships of humans to the biophysical environment. ${ }^{134}$ As with law in general, environmental law can be helpfully conceptualized in terms of three basic forms or phases. At the same

133 The key here is that the competition is not limited to a competition for business, but is also a competition to establish a legal order that will support that business. At the same time, contrary to the way many economists and some institutionalists conceive law, the legal order is not really fixed, but rather dynamic and subject to constant competition. DEZALAY \& GARTH, supra note 124, at 16. 134 There are risks to such a broad definition, primarily of taking in such a huge and unwieldy area that it resists meaningful conceptualization. The recent histories of the subfields, however, indicate a need to deal with interconnections among them. Protecting an endangered arctic species, for example, may require controlling land use in North America as well as the use of organic pesticides in the tropics. Accordingly, it seems unlikely that a narrower definition of the field would fruitful in either the near or the long term. 
time, it is important to understand that the phases are not completely distinct, and that elements of each phase can be found in the others. ${ }^{135}$

\section{Phase 1}

Before the $19^{\text {th }}$ century, most environmental law appears to have been made in civil society. It typically took the form of either generally accepted customs or rules developed by assemblies of appropriate estate holders or other interested members of society. There is little published research on this phase of environmental law, most likely because many scholars uncritically think of environmental law as a product of the $19^{\text {th }}$ century, when the control of industrial discharges came to be widely seen as necessary. My exploratory review of early English legal history, however, has found a great deal of environmental regulation in the medieval period. Typical laws covered how many sheep and cattle could be grazed, where and when, how water runoff must be managed, how land fertility was to be preserved, and so on.

The details of these regulations and how they were worked out are well beyond the scope of this paper, but it is helpful to describe a few typical institutional practices. First, although environmental laws usually were not voted upon nor based upon a principle of political equality, they were generally discussed quite thoroughly in village, town, or manorial assemblies. Most interested farmers and villagers probably had a 'voice' and would be heard in those assemblies. At the same time, the views of certain 'men of substance' (not necessarily free holders) generally counted most, and the resulting bylaws tended to reflect the interests of the better off community members. ${ }^{136}$ It is also apparent that in most cases regulations were not simply dictated or imposed by officials. Whether or not the lord of the manor could in principle set the rules under which the manor and village operated, it

\footnotetext{
135 E.g., David Westbrook, Liberal Environmental Jurisprudence, 27 U.C.D.L.R.619, 619-712 (1994).

136 WARREN O. AULT, OPEN-FIELD HUSBANDRY AND THE VILLAGE
} COMMUNITY: A STUDY OF AGRARIAN BY-LAWS IN MEDIEVAL ENGLAND 42 (1965). 


\section{BUFFALO ENVIRONMENTAL LAW JOURNAL [Vol.10}

is clear that he did not do so for most natural resource and environmental regulations. These were more typically worked out by concerned groups of citizens and then sometimes ratified by the lord. Depending on the village of origin environmental laws might be described as ordained "by the whole homage and by the freemen", "by the whole township", "by the community of the town", "by the lord and the community of the town", "by the whole homage of the town", "by the lord and his tenants", "by all the tenants, free and customary", or "by the assent of all the homage". 137

Over time, the rules and policies thus worked out in customary social institutions were gradually incorporated into definitions of property rights, primarily through real property, servitude, ${ }^{138}$ and nuisance doctrines. This was done first by local courts and eventually by the royal courts and other agents of the crown, thus mirroring the general processes for incorporating guild-made rules into governmental law discussed above. As the origins of the property based environmental regulations receded into history, they may have begun to appear as if they had been created and imposed by the state in the first place.

At the same time, however, the conflicts created by rapid urbanization and industrialization in the late $18^{\text {th }}$ and throughout the $19^{\text {th }}$ century created new conflicts that were difficult to handle in terms of received property rights. In trying to resolve them courts increasingly asked whether contested land uses were 'nuisances.'

Traditional nuisance doctrine typically asked whether a specific resource use fit or was appropriate in a given place, thus again implicitly ratifying received civil society arrangements. But the static and yet somewhat unpredictable implications of such an approach brought increasing pressures on the courts to rationalize and universalize their decisions. Thus courts came to define the central question as whether a land use was "unreasonable" under the

\footnotetext{
$137 \quad$ Id. at 41.

138 The term "servitude" is used here to include uses and constraints on property use that often are separately categorized as easements, covenants, and equitable servitudes in Anglo-American law.
} 
circumstances. This question invited judges to determine the proper use of land in a changing society, and perhaps even to balance the relative costs and benefits of alternative land uses.

At the same time, such questions were being taken up by legislative bodies, and sometimes by newly established administrative agencies as well, thus inaugurating institutional structures characteristic of Phase 2.

\section{Phase 2}

Although the "modern" era of environmental law often is portrayed as starting in the late 1960 s or early 1970 s, its institutional roots go back a hundred years earlier. By the end of the $19^{\text {th }}$ century, legislatures and administrative agencies were beginning to address environmental issues, promulgating a miscellany of laws directed at air and water pollution, as well as wildlife and forest destruction, and typically assigning their enforcement to administrative agencies attributed with expertise in handling such problems. ${ }^{139}$ In some countries this was done primarily at the local or provincial level, in others at the national level. ${ }^{140}$ On the whole, these laws appear to have been relatively ineffectual for a half century or more, due primarily to weak scientific foundations, relentless industrialization, and lackadaisical enforcement reflecting preferences in most jurisdictions for economic growth over environmental protection. ${ }^{141}$ After World War

139 There were striking and important precedents, of course. In England, for example, a 1388 Parliamentary statute forbade the deposit of "Dung and Filth of the Garbage and Intrails as well as of Beasts killed, as of other Corruptions ... in Ditches, Rivers, and other Waters," and required anyone who had made such deposits to remove them or be fined. It also provided for citizen enforcement of the law. Statute of 12 Rich. II. Ch.13 (1388).

$140 \quad$ Formally, the level made little difference because local and provincial governments by this time were defined as creatures of the state. J.F. DILLON, COMMENTARIES ON THE LAW OF MUNICIPAL CORPORATIONS $\$ \$ 237-39$ (5th ed. 1911).

141 E.g., JAN LAITOS, A LEGAL-ECONOMIC HISTORY OF AIR POLLUTION CONTROLS (1980). 
II the situation slowly began to change, as the impacts of industrial pollution became more widespread and better understood. ${ }^{142}$

By the 1970s and 1980s most industrialized countries had established extensive statutory and administrative systems to protect air, water, land, and biodiversity. The systems are so extensive, and grow so steadily, that they are extremely difficult to understand or conceptualize. They range across an enormous array of subjects, running from nuclear power to endangered species, from historic preservation to genetically modified organisms, and so on. ${ }^{143}$ They typically involve great technological and scientific complexity, and face enormous uncertainty. They almost always encounter unanticipated interconnections and problems. Finally, they often involve difficult normative choices that can trigger or exacerbate social conflict. In sum, they require combining sophisticated political processes with sophisticated scientific ones. Not surprisingly, the challenges of making and revising environmental law can be staggering.

The complex of institutional methods primarily relied upon by government legal systems to meet these challenges in Phase 2 is often derisively and somewhat unfairly called "command-and-control" regulation. Because this form of environmental law has been so exhaustively studied and described as to be generally familiar to most readers, I will only note its most basic institutional characteristics here.

The core regulatory mechanism of Phase 2 environmental law is the requirement that categories of polluters and other natural resource users keep their environmental impacts at levels which would result from application of the strictest feasible technological methods to their production processes. Thus, although they usually do not

\footnotetext{
142 (1981).

E.g., ERIC ASHBY \& MARY ANDERSON, THE POlITICS OF CleAN AIR

${ }_{143}$ E.g., Zygmunt J.B. Plater, Environmental Law and Three Economies: Navigating a Sprawling Field of Study, Practice, and Societal Governance in Which Everything is Connected to Everything Else, 23 HARV. ENVTL. L. REV. 359, 359-92 (1999).
} 
require the actual use of a specific technology, these requirements are typically referred to by names such as "best available control technology" and "best management practices."

The standards are generally defined by administrative agencies for specific industries through rule-making and adjudication processes. They often are set with little regard to collateral environmental issues, such as waste production or consumption of scarce resources. Pre-existing plants and activities generally are treated more leniently than proposed ones. Actual implementation of standards varies considerably among jurisdictions, both within and among countries. The costs and levels of protection thus also vary among both firms and sectors. Like any important institutional synthesis, Phase 2 has given rise to a set of institutional antitheses in Phase 3.

\section{Phase 3}

Phase 3 consists of a number of loosely related reform initiatives, including market mechanisms, information disclosure requirements, flexible permitting programs, regulatory negotiation, ecosystem management, place-based collaborative management initiatives, voluntary agreements, good neighbor agreements, and environmental certification programs. Many grow out of critiques of Phase 2 regulation, although some go back farther. Overlaid on Phase 2 regulation, the overall picture constituted by these initiatives suggests that environmental law is in considerable flux, and may be quite hospitable to the emergence of civil society regulatory initiatives such as forest certification.

Market Mechanisms effectively attach prices to environmentally damaging activities and allow firms to reduce the damage if doing so is cost-effective, or to pay others or pay taxes if the costs of reduction are higher than the payments or taxes. Market mechanisms are a response to the most influential critique of traditional regulation, which holds that it is needlessly inefficient, costing more than necessary to achieve a given level of social benefits. This is because control technology standards are based on feasibility for general 


\section{BUFFALO ENVIRONMENTAL LAW JOURNAL [Vol.10}

categories of polluters, rather than on individually tailored cost-benefit criteria. Thus, one firm or sector can be required to incur significantly higher costs than another would to obtain any given level social benefits. ${ }^{144}$ Market mechanisms seek to obtain environmental benefits where they are least costly, and thus to minimize the total costs to society of environmental protection.

Two other important initiatives also respond in large part to this critique. The first is to document means-ends, or cause-effect relationships between regulatory strategies and environmental goals. This of course requires a significant expansion in the quality of scientific information and models. A second and related initiative is to undertake comparative risk assessment of environmental regulation, so that resources and costs will be focused on the most risky activities. This is a very difficult undertaking making huge demands on science. The available scientific information and models are flexible enough that huge disagreements persist about the comparative risks of various activities.

Although the practical role of market mechanisms remains limited, it has been expanding for over two decades. At the formal level, agencies have developed a number of programs, such as the "offsetting", "bubbling" and acid rain trading programs in United States air pollution regulation. At the informal level, too, regulatory officials appear to allow a certain amount of "bubbling" in individual pollution permits, even when statutes and rules do not provide for it. Market mechanisms are regularly extended into new regulatory territory. The State of California, for example, recently established an "endangered species mitigation bank," whereby landowners can earn "conservation credits" by taking steps to permanently protect endangered species on one site and can then sell their credits to

144 On the benefit side, the argument was also made that uniform standards among jurisdictions are undesirable, because the benefits will vary greatly depending on population density, concentration of pollution sources, natural conditions, and so on. JAMES KRIER \& EDMUND URSIN, POLLUTION AND POLICY: A CASE ESSAY ON CALIFORNIA AND FEDERAL EXPERIENCE WITH MOTOR VEHICLE AIR POLLUTION, 1940-975 (1977). 
developers seeking to carry out projects that might harm those species on other sites. ${ }^{145}$

Information Disclosure Requirements also appear to be expanding steadily in environmental law. The basic strategy is to require firms that handle dangerous substances or engage in other potentially harmful activities to publicly disclose those activities. The paradigmatic example is the United States "Community Right to Know" law, which requires that anyone who stores or discharges more than set amounts of any of a list of approximately 600 toxic chemicals to the air, land, or water must publicly disclose the types and amounts of chemicals involved. This must be done regardless of whether the activities are legal or illegal, regulated or unregulated. Since its passage in 1987, the law appears to have had a large effect on the discharge of hazardous chemicals, possibly reducing them by over one-third..$^{146}$ This kind of "transparency" strategy is not cost-free, but is significantly less costly than traditional regulatory standard setting. Some scholars view the emergence of information disclosure requirements as a major step toward "reflexive" environmental law designed to make actors reflect upon the consequences of their acts and adjust to make them socially acceptable. ${ }^{147}$ Others find them to constitute a major expansion in the ability of wider communities to

\footnotetext{
145 Michael J. Bean \& Lynn E. Dwyer, Mitigation Banking as an Endangered Species Conservation Tool, 30 ENVTL. L. REP. 10537, 10537-551 (2000).

146 E.g., Bradley C. Karkainnen, Information as Environmental Regulation:

TRI and Performance Benchmarking, Precursor to a New Paradigm?, 89 GEO. L.J. 257, 257-370 (2001); Toxic Release Inventory: Community Right-To-Know, at http://epa.gov./tri/tridata/tri99/press/backgrd_factors.pdf. Mazurek suggests, however, that some of these effects may be artifacts of tendencies by transnational companies to relocate polluting activities to jurisdictions lacking comparable disclosure laws or to outsource them to small companies that fall beneath threshold reporting requirements. JAN MAZUREK, MAKING MICROCHIPS: POLICY, Globalization, AND ECONOMIC RESTRUCTURING IN THE SEMICONDUCTOR INDUSTRY (1999).

147 E.g., Eric W. Orts, Reflexive Environmental Law, 89 Nw. U. L. REV. $1227,1227-339$ (1995).
} 
monitor and set benchmarks for the performance of corporations. ${ }^{148}$ State imposed disclosure requirements can thus be seen as valuable resources for civil society regulatory institutions.

Flexible Permitting Programs allow firms to avoid specific regulatory requirements in return for showing that they can provide equal or greater environmental benefits by other, presumably less costly means. Flexible permitting programs respond to some of the same critiques of command-and-control regulation as market mechanisms, but give the regulatory agency a more direct role in the decisional processes. Examples include "Project XL" in the United States and the Eco-Management and Auditing Scheme ("EMAS") 149 in the European Union. Rather than simply creating legally protected interests that can be traded, the government agency creates a framework in which firm are invited to be innovative to the benefit of the public, subject to some sort of check and ratification by the administrative agency.

The record of flexible permitting processes is unclear at this stage. In the U.S., flexible permitting seems to have fallen short of expectations, creating just about as many procedural hurdles and business costs as it eliminated ${ }^{150}$ and stimulating relatively little environmental improvement. Recently, however, the EPA has established a new, ostensibly improved program called Performance Track, which relies more heavily on environmental management

148

E.g., Karkkainen, supra note 146. At the same time, it is important to note that modern environmental systems still face severe and possibly increasing information disparities. Thus while it is true that the amount of public information seems to be growing absolutely in most industrial societies, the amount of private information, much of it given proprietary protection, may be growing even more quickly.

149 EEC Council Regulation $1836 / 93$ (authorizing voluntary participation by industrial firms in a community eco-management and audit scheme) 1993 O.J. (L 168) 1. The primary benefits of EMAS participation for companies appear to be extended time frames for regulatory compliance and reduced penalties for noncompliance.

1so U.S. Environmental Protection Agency, Nat'l Envtl. Performance Track at http://www.epa.gov/performancetrack. 
systems and non-governmental environmental certification programs such as ISO 14001. ${ }^{\text {ISI }}$ EMAS, which also includes a substantial EMS component, ${ }^{152}$ seems to be viewed as more of a success in Europe, although it too has fallen short of expectations. Nonetheless, these programs persist and seem to be growing, as agencies work to improve them in successive iterations.

Regulatory Negotiation ("reg-neg") is a rule-making process in which a government regulatory agency organizes a stakeholder group and commissions it to draft a proposed rule addressing a specific problem. The stakeholder group is supposed to represent all important affected groups, to be willing to bargain in good faith, and to seek consensus. Agencies are advised to use this method for problems that are not likely to be highly contentious, nor require participants to compromise their fundamental commitments. ${ }^{153}$ When the regulatory negotiation process is complete the agency subjects the proposed rule to a slightly streamlined version of its traditional rule making processes, but remains responsible for the ultimate content of the rule.

Reg-Neg processes have been used in a large number of environmental rule-makings since the mid-1980s, although impressionistic evidence suggests that their popularity in the United

$151 \quad$ Id.

152 Each company participating in the EMAS program prepares an environmental management system incorporating sevèral principles, including pollution prevention and source reduction. The environmental management system must include: (a) specific definitions of management responsibilities in the company for environment matters; (b) a register summarizing the effects that the company's operations on the environment; (c) environmental record keeping and reporting procedures; (d) a public environmental statement listing significant environmental issues and emissions; and (e) periodic audits of the company's management system, with verification of the audits by an external auditor. Participating companies have the right to register with their national governments and to be included in a list of EMAS companies published in the Official Journal of the European Union. The companies are also permitted to advertise publicly their participation in the program. Id.

153 ADMINISTRATIVE CONFERENCE OF THE UNITED STATES: NEGOTIATED RULEMAKING SOURCEBOOK at 37-41(1990). 


\section{BUFFALO ENVIRONMENTAL LAW JOURNAL [Vol.10}

States may have leveled off recently. Evaluations of the process are contentious. Some commentators argue that reg-neg has provided for a forum in which regulatory problems are effectively redefined, innovative solutions found, and new institutions developed. ${ }^{154}$ Others assert that they have not reduced regulatory costs, conflict, or litigation, ${ }^{155}$ and have dangerously transferred regulatory power to private interests, a form of "capture". ${ }^{156}$

Ecosystem Management seeks to integrate the many environmental and social interconnections implicated in all significant environmental management decisions. Its goal is to correct for the shortcomings of single-purpose and single-technique environmental actors, both private and public. Ecosystem management attempts to do this by locating all significant actors and their activities in a broad scale ecological framework and addressing the complex ecological and social interactions among them. Often it also seeks to link "environmental" issues to social and economic ones such as community maintenance and job creation, thus partaking in the postRio 'sustainable development' framework. In doing so, most ecosystem management initiatives attempt to combine a comprehensive analytical methodology with broad stakeholder collaboration. An important driver of ecosystem management is the recognition that the fragmentation of jurisdiction over the natural environment among many governments and property holders leaves none of them in a position to achieve integrated management on its own. Integrated, ongoing stakeholder collaboration is necessary to make, assess, and revise environmental policy. ${ }^{157}$

154 Jody Freeman, Collaborative Governance in the Administrative State, 45 UCLA L. REV. 1, 1-98 (1997).

iss Cary Coglianese, Assessing Consensus: The Promise and Performance of Negotiated Rulemaking, 46 DUKE L.J 255, 255-1349 (1997).

156 William Funk, Bargaining Toward a New Millennium: Regulatory Negotiation and the Subversion of the Public Interest, 46 DUKE L. J. 1351, 1351388 (1997).

157 Errol Meidinger, Legal and Institutional Challenges of Ecosystem Management, in CREATING A FORESTRY FOR THE 21ST CENTURY: THE SCIENCE OF ECOSYSTEM MANAGEMENT (Kathryn A. Kohm \& Jerry F. Franklin eds., 1997), 
Ecosystem management has been a "top-down" strategy on the whole, conceived primarily by ecologists and centralized government agencies and NGOs. At the same time, governments and government agencies are often only one or two members of the broader group of stakeholders, although they sometimes play a controlling role. To date, the legal framework for ecosystem management appears to consist primarily of memoranda of understanding among units of government and contractual agreements among government agencies and landholders. Ecosystem management proponents in the United States have generally not sought amendments or new authority in statutes, ${ }^{158}$ evidently out of a fear of "opening up" environmental statutes to the risk of weakening amendments.

Place-Based Collaborative Management Initiatives are closely related to ecosystem management ones, but have typically been more bottom-up, self-organized processes. They are often established on a "watershed" basis, on the underlying theory that actors in a watershed are mutually dependent upon each other, and would be well advised to work out mutually acceptable understandings of proper environmental management. The watershed frame also provides a basis for deciding who the participants should be.The specific focci of placebased groups vary with the environmental management issues relevant to the particular place. They often involve water quality, fisheries, and forest management, although the scope of issues can expand beyond traditional environmental ones to include social and economic ones. The United States EPA estimates that there are currently over 3000 local watershed management groups in the United States. ${ }^{159}$

Some place-based groups have evolved very definite structures of rights and responsibilities, enforceable through legal or informal

available at http://www.law.buffalo.edu/homepage/eemeid/scholarship/ orglegchal.htm.

158 INTERAGENCY ECOSYSTEMMANAGEMENT TASK FORCE, THE ECOSYSTEM APPROACH: HEALTHY ECOSYSTEMS AND SUSTAINABLE ECONOMIES (1995).

159 Christine Lewicki, Governing by Watersheds-A National Trend, Address to the Conference on Learning Sustainability (Oct. 10-13, 2001). 


\section{BUFFALO ENVIRONMENTAL LAW JOURNAL [Vol.10}

sanctions ${ }^{160}$ whereas others have much looser, more fluid arrangements in which members come and go. ${ }^{161}$ Again, government bodies sometimes participate in place-based management initiatives, but generally more as stakeholders than as sovereigns. In recent years governments seem increasingly inclined to take steps to facilitate place based management processes, thus giving them some "topdown" impetus as well. In the US, for example, the EPA has encouraged states to set up watershed management groups to set and allocate "total maximum daily loads" of pollution for particular watersheds under the CWA. ${ }^{162}$

Voluntary Agreements typically are "one-shot" deals negotiated between government agencies and firms in which the firms commit to improving their environmental performance beyond what is required under existing law. They differ from flexible permits in that there is no pre-defined framework in which they are worked out, and they are therefore difficult to incorporate systematically in environmental law. ${ }^{163}$ Voluntary agreements are extremely common in Japan, and quite common in some European countries. ${ }^{164}$ They can be negotiated at the national, regional, or local level. Although local governments seem particularly vulnerable to informational and negotiating inequalities in relation to firms, there are good arguments that voluntary agreements allow governments to achieve higher levels

160 E.g., EVELYN PINKERTON \& MARTIN WEINSTEIN, FISHERIES THAT WORK: SUSTAINABILITY THROUGH COMMUNITY-BASED MANAGEMENT (1995).

161 For a description and critical analysis of the Applegate Partnership, see Stephen M. Nickelsberg, Note: Mere Volunteers? The Promise and Limits of Community-Based Environmental Protection, 84 VA. L. REV. 1371, 1371-409 (1998), which is one of the best known and most influential of the American placebased collaborative management initiatives.

162 Oliver A. HOUCK, THE Clean Water Act TMDL Program: LAW, POLICY, AND IMPLEMENTATION (1999).

163 Dietrich Murswiek, Das sogennannte Kooperationsprinzip-ein Prinzip des Umweltschutzes, 12 ZEITSCHRIFT FUR UMWELTRECHT 7, 7-13 (2001).

164 CARLO CARRARO \& FRANCOIS LEVEQUE, VOLUNTARY APPROACHES IN ENVIRONMENTAL POLICY (1999). 
of environmental protection than they otherwise would. ${ }^{165}$

"Good Neighbor Agreements" are somewhat like traditional voluntary agreements, but are negotiated between firms and community groups or other civil society organizations, rather than between firms and governments. ${ }^{166}$ It is impossible to say how many exist, but they seem to be multiplying rapidly, facilitated to some extent by the public information, participation, and review requirements of government regulatory programs. Good neighbor agreements often are very sophisticated arrangements, approximating or exceeding the detail and coverage of permit documents prepared by regulatory agencies. ${ }^{167}$ They generally seek to achieve environmental performance superior to that government agencies are able to require, and largely cut government out of the deal, leaving it only as a background player. Contract law and private land use agreements often are used to help assure compliance.

Environmental Certification Programs provide frameworks in which firms can be certified as practicing good environmental management. Some, such as the chemical industry's "Responsible Care" program ${ }^{168}$ and the United States forest product industry's Sustainable Forestry Initiative, are run by industry trade associations. Others, such as the ISO 14001 program, are run by inter-sectoral industry-based groups, some of which are government sanctioned. Still others, such as the Forest Stewardship Council, are established by NGO-based groups. Depending on the program, firms are entitled to signal their certification status by displaying labels on their literature, facilities, or products. ISO-type programs focus on the implementation of sophisticated environmental management systems

165 Rehbinder, supra note 79; Id.

166 R. Nils Olsen Jr., The Concentration of Commercial Hazardous Waste Facilities in the WNY Community, 39 BUFF. L. REV. 473, 473-522 (1991).

167 E.g., Stillwater Mine, Good Neighbor Agreement between Stillwater Mining Company and Northern Plain Resources Council and Others (2000), at http://www.nprcmt.org/Good\%20Neighbor\%20Agreement-complete.htm.

168 Neil Gunningham, Environment, Self-Regulation, and the Chemical Industry: Assessing Responsible Care, 17 LAW \& POL'Y 57, 57-109 (1995). 
("EMS"s) by firms, ${ }^{169}$ while FSC-type programs focus on performance requirements. The performance requirements almost always include traditional pollution and biodiversity concerns, but some are now extending to include economic, community, and labor ones as well.

Taken together, the above-described initiatives indicate great churning in the field of environmental law. Most of them expand the role of civil society organizations in domestic environmental law. For the most part, civil society institutions do not seem to displace government ones, but rather enter open-ended cooperative and partnership relationships with them. ${ }^{170}$ Government agencies generally remain dominant, but rely heavily on extra-governmental processes and relationships, and often operate in horizontal rather than vertical relationships with them. Although it is difficult to generalize about such a diverse set of initiatives, it seems safe to predict that they will lead to increased incorporation of civil society norms and institutions into governmental regulation, making it all the more important to monitor civil society regulatory institutions. It also seems possible that the new initiatives portend fundamentally more complex and contentious legal processes, as the roles and responsibilities of various governmental and non-governmental actors overlap and blur. These problems seem especially likely if the tendency to integrate traditionally separate economic and social concerns expands, concomitantly expanding both the number of interested actors and the inherent conceptual and informational challenges.

\section{Global}

Global environmental law has a history broadly similar to its domestic counterpart, but much briefer and less accomplished. Before World War II there was very little international environmental law, the

\footnotetext{
169 COGLIANESE \& NASH, supra note 12.

170 Cf. Jody Freeman, Collaborative Governance in the Administrative State, 45 N.Y.U. L. REV. 1, 1-98; Meidinger, supra note 4; Stepan Wood, Voluntary Environmental Standards: Green Revolution or Greenwash?, in SOCIAL RELATIONSHIPS: REFOCUSING THE PUBLIC/PRIVATE DIVIDE (forthcoming).
} 
primary exceptions being treaties to protect migratory birds and a few international water bodies. Since World War II the pace has accelerated considerably, with a raft of treaties and cases seeking to protect transnational environmental resources. ${ }^{171}$ Important examples include the Montreal Protocol on Substances that Deplete the Ozone Layer ("Montreal Protocol") and the Convention on International Trade in Endangered Species of Wild Fauna and Flora ("CITES"), as well as the soon-to-be-ratified Stockholm Convention on Persistent Organic Pollutants ("POPs Convention").

On the whole, however, progress through the Westphalian system of nation-state negotiations has been painfully slow, while the growth of serious transnational environmental problems has been remarkably rapid. Problems such as global climate change, biodiversity loss, ocean degradation, decertification, drinking water degradation, and hazardous and nuclear waste mismanagement have not been effectively addressed by the Westphalian system. Even where treaties exist, their enforceability and adaptability to change often are subject to serious doubt. Finally, the growing promotion of international trade, and the distrust of regulations that could conceivably constitute non-tariff trade barriers, create international obstacles to improved domestic environmental regulation.

Given the limited capacity and achievements of Westphalian institutions, it is not surprising that global civil society organizations would attempt to fill the gap. As noted in the introduction, it was the failure of international institutions to protect tropical forests that spurred the growth of forest certification in the first place. For this reason and because of the law-like nature and structure of forest certification, it is in the ironic position of being faced with the same questions confronting traditional legal systems.

$171 \quad$ KISS \& SHELTON, supra note 72. 


\section{Forest Certification as Environmental Law}

This section treats forest certification as a form of environmental law and starts to ask some of the questions regarding certification that are asked of environmental law. Of the many possible criteria that could be deployed and their variants, this paper focuses on four general areas: efficacy, coherence, adaptability, and legitimacy. Its goal is more to clarify and frame important questions than to answer them at this stage, although some working hypotheses are offered.

\section{Efficacy}

In modern times, the criterion most frequently invoked to evaluate legal systems is that of efficacy. ${ }^{172}$ Its core question is whether the legal system effectively governs how people interact in a given field. In the case of environmental law, the question is whether the legal system effectively governs human relationships to the biophysical environment. Ironically, there has been very little research on the overall efficacy of Phase 1 and Phase 2 environmental law systems. This is in part because of the enormous difficulty, if not impossibility, of attributing cause and effect relationships to such large phenomena.

There is also an important and contested preliminary problem: efficacy toward what end? Neither the traditional environmental law system nor forest certification have come up with a clearly defined end. Indeed, as suggested above, part of the operation of any legal system focuses on defining the goals of the system. Environmental law and forest certification are caught up in larger societal dialogues on environmental policy. In the past two decades societal conceptions of environmental regulation have begun to shift from relatively narrow, negative conceptions of controlling pollution and other destructive practices toward broader, more affirmative conceptions of achieving sustainability and sustainable development. These affirma- 
tive conceptions include important social and economic goals, such as economic vitality and community stability. For this reason alone they are harder than negative goals to operationalize, and their achievement is accordingly harder to "certify." In fact, the difficulty of documenting sustainability prompted the Forest Stewardship Council to redefine what its program certifies, from "sustainably" to "well" managed forests.

Nonetheless, there has been considerable discussion about the efficacy of forest certification, mostly focusing on how well it protects the environment. ${ }^{173}$ The first level has debated the comparative advantages of programs based on substantive standards versus those based on environmental management systems. ${ }^{174}$ The second level has debated the comparative effects of different standards-based systems. ${ }^{175}$ Although some of this debate is based on limited empirical research, most of it is hypothetical-deductive in form. In other words, it assumes that standards will be fully implemented and then compares the assumed effects of the standards. Similarly, standards systems and environmental management systems are compared based on analysts' assumptions about how they will work in practice. These assumptions often are based on a queasy mix of real-world experience and commitment to different management philosophies and even theories of social control.

173 This is not surprising, since there is broad agreement across legal systems that protection of environmental resources, particularly those that are valuable to humans, is a core goal of environmental law. Thomas Lundmark, Systematizing Environmental Law and Policy, 7 Dick. J. ENVTL. L. \& POL'Y 1, 9 (1998). It does, however, fall short of addressing the post-Rio environment-society-economy goals of sustainable development.

174 E.g., Pierre Hauselmann, ISO Inside Out: ISO and Environmental Management (1997)(WWF Int'l discussion paper, Geneva); RIVA KRUT \& HARRIS GLECKMAN, ISO 14001: A MISSED OPPORTUNITY FOR SUSTAINABLE GLOBAL INDUSTRIAL DEVELOPMENT (1998).

175 E.g., CEPI, supra note 65; MERIDIAN INSTITUTE, COMPRATIVE ANALYSIS OF THE FOREST STEWARDSHIP COUNCIL $\$$ AND SUSTAINABLE FORESTRY InITIATIVE@ CERTIFICATION PROGRAMS (2001), at http://www.merid.org/ comparison. 
Many of the analyses that have been done are useful in that they clarify the terms and structures of certification programs. And despite my critical posture, it is my impression that forest certification programs are leading to some improvements in forest management. ${ }^{176}$ Still, we know very little about why or where or under what conditions. And debates regarding the relative merits of different approaches probably cannot be sorted out at this point because we lack anything remotely approximating evaluation research.

The absence of rigorous evaluation research on forest certification is somewhat ironic, since the efficacy of certification systems is in principle easier to research than the efficacy of more multi-faceted legal systems. If proper evaluation research were to be done, comparable firms would be randomly assigned either to be certified or not. The certification group would also be randomly assigned to different certification programs so that the programs could be compared. ${ }^{177}$ The performance of the firms would be measured before and after certification, ideally at regular intervals. Typical performance of certified and non-certified firms could then be compared by program.

Systematic evaluation research is quite unlikely to be done, however, for two basic reasons. First, because certification programs are self-defined as voluntary there is a significant problem with 'selection effects.' Firms choose whether or not to participate in certification programs based on their individual assessments of what is in their best interest. It is therefore likely that significant prior differences exist between firms that enter certification programs and those that do not, and between firms that enter different certification programs or enter them at different times. Accordingly, differences in their performance over time are as likely to be correlated with

\footnotetext{
176 See generally Meidinger, supra note 4, at 164, 199, 217.

177 See generally DONALD T. CAMPBELL \& JULIAN C. STANLEY, EXPERIMENTAL AND QUASI-EXPERIMENTAL DESIGNS FOR RESEARCH (1963).
} 
underlying differences among firms, as with differences in the programs per se. ${ }^{178}$

Second, certification programs are not designed to produce detailed, comparative data on the performance of forest enterprises. Rather, the whole point of certification is to make a binary classification: certified or not-certified. Firms within the certified category are portrayed as if they were homogenous in performance. The primary site-specific information provided by certification programs is the label itself. The label can be matched up with the standards and criteria on which it is based, but the standards and criteria are general, and do not provide any further information on the particular enterprise. If such information is to be provided, it must come from voluntary action of the firm or compulsory mandates of other regulators, usually governments. This situation exposes a second level of irony: some of the attraction of certification to firms may derive from its potential to stave off mandatory regulatory disclosure of more detailed information on their operations.

In sum, we do not have and are not likely to get anything approximating scientifically persuasive information on the efficacy of forest certification programs. This does not mean, however, that we are incapable of making efficacy assessments and recommendations. Research on other areas of regulation suggests several areas of concern which will have to be dealt with over time as certification systems assess their efficacy and seek to reconfigure themselves. I raise them here in an attempt to spur discussion as early as possible. Given that forest certification is only one forest regulatory system among several, it is useful to consider efficacy from both an internal and external standpoint.

178 This is a more general version of the argument that firms seeking certification are likely to be good performers regardless of whether they undertake certification. E.g., Kirsti Thornber et al., Certification: Barriers to Benefits: A Discussion of Equity Implications (1999) (European Forestry Institute Discussion Paper No. 8). 


\section{BUFFALO ENVIRONMENTAL LAW JOURNAL [Vol.10}

\section{Internal}

Viewed internally, regulatory systems can be understood primarily as seeking to control the behavior of their direct "targets"typically regulated firms. We have a great deal of experience with command and control regulation which might be useful to forest certification. In this section I will touch on only a few issues that seem most immediate.

Accountability. ${ }^{179}$ At present certification systems are built on a three part accountability structure: policy maker/accreditor_certifier_forest management organization. This is a rough approximation of the agency_inspector_regulated firm structure typical of governmental regulation, but there are several important differences. First, many certification systems seek to improve the compliance of organizations by institutionalizing controls within the firm in the form of environmental management systems. Many governmental regulatory programs are also pursuing such strategies, but there is little information as yet on how they work. As I have suggested above and elsewhere,${ }^{180}$ it is hard to believe that environmental management systems will have no effect on firm behavior. On the whole, they seem likely to lead to improvements, simply because they give specific actors in management organizations specific responsibilities for specific issues-whereas before these elements were often highly diffuse or absent in the management organizations. We just do not know how much improvement there is or under what circumstances.

The second important difference is that certifiers are not employees of the certification programs. Rather, they are hired and paid by firms seeking to be certified. Experience with other regulatory programs suggests that this situation has the potential to lead to at

179 This paper focuses on internal program accountability and control. The bigger question of democratic accountability to the public, E.g., Spiro, supra note 126 , is left for a later paper.

180 Meidinger, supra note 4, at 199-203. 
least to major types of problems: limited enforcement resources and risks of corruption.

Limited Enforcement Resources. The resources available to certifiers to monitor compliance come from the firms being monitored, and are fundamentally limited by the total magnitude of certification revenues. This means it will be difficult for certifiers to concentrate resources on monitoring firms in the way an administrative agency might, for example, focus its resources on particular companies thought likely to present special problems. Certifiers will generally be hard pressed to set their fees for any particular firm higher than the costs of certifying that firm in order to pay for surveillance of other firms. It may be possible for certification firms to call for help with extra resources from environmental NGOs or foundations in particularly difficult circumstances, but it does not seem likely that they will be able to do so on a regular or continuing basis.

Risk of Corruption. Second, there is a serious risk of what as well be labeled corruption, despite the term's powerful overtones. By corruption I simply mean allowing one's official judgments to be influenced by self-interest in a way that is inconsistent with one's official duties. Because of their need for continuing revenues, certifiers are highly dependent on firms seeking certification and are under pressures to satisfy them. This is particularly true of the ISO 14001 and AF\&PA Sustainable Forestry Initiative programs, but also applies to the FSC program. Certifiers have strong interests in pleasing their employers, and are likely to be selected in part because they are expected to sympathize with the viewpoints of their employers. ${ }^{181}$ At the same time, of course, the reason certifiers are

181 For a critical analysis of PriceWaterhouseCoopers auditing of clothing manufacturers, see Dara O'Rourke, Monitoring the Monitors: A Critique of PriceWaterhouseCoopers Labor Monitoring (2000) at http://web.mit.edu/dorourke /www/PDF/pwc.pdf. For an argument that auditors suffer from an inherent "selfserving bias" see Robert A. Prentice, The SEC and MDP: Implications of the SelfServing Bias for Independent Auditing, 61 OHIO ST. L. J. 1597, 1597-664 (2000). 


\section{BUFFALO ENVIRONMENTAL LAW JOURNAL [Vol.10}

employed is to provide assurance to the public that the firms employing them in fact are performing as advertised.

Certifiers are thus placed in an inherently difficult position, since they are in effect public fiduciaries employed by the very private actors whose activities they are supposed to assess and monitor. To date, in my estimation, the public discussion and analysis of this problem in the forest certification arena has been quite limited and exceedingly naïve. This is probably due in part to the fact that the primary basis of reliability attributed to certifiers is professionalism, and the discussion has taken place primarily among forestry professionals. We know from the history of other fiduciary professions, however, including accounting and law, that other safeguards are important and perhaps essential.

Institutional Safeguards. At present there are very few structural safeguards against corruption in forest certification. The primary one in the case of the FSC is periodic auditing of certifiers' decisions by FSC staff. Although this process recently led to the suspension of one certifier's privileges, ${ }^{182}$ the oversight resources of the FSC are very limited, and are likely to remain so for the foreseeable future. The AF\&PA system evidently provides for no auditing of certifiers at all, and indeed makes them even more dependent on firms than the FSC system. The AF\&PA has provided, however, for a rudimentary external complaint system wherein people who believe they have information indicating that a member company is not conforming to SFI guidelines can submit that information to someone who will keep their identities confidential. This is a start toward creating a more adequate accountability structure, but a very limited and probably quite inadequate one, because there are likely to be few cases in which

182 The certification organization involved was SKAL, based in the Netherlands, which was temporarily deprived of its authority to issue new certificates. FSC headquarters circular to National Initiatives (April 9, 2001) (on file with author). It was reinstated about a month later, after undergoing intensive discussions and a training session. Memorandum from Karen Tam, Operations Officer to FSC Members, (May 11, 2001) (on file with author). 
people have the necessary combination of information and adversity to file complaints.

Research on regulatory institutions has produced a broad consensus that triangulation of social accountability structures is important to regulatory efficacy. The key idea is to empower third parties to monitor the performance of both regulators and regulatees. ${ }^{183}$ The third parties may be organized groups, or they may be more diffuse actors such as citizens. Many institutional mechanisms exist for achieving triangulation. Perhaps the most important in environmental regulation are "citizen suit" and various "transparency" and public information devices. A citizen suit mechanism empowers parties aggrieved by non-compliance with a rule to bring legal enforcement actions directly against the violator, with or without action by the government regulator. ${ }^{184}$ Transparency mechanisms give aggrieved parties information with which to publicize the misbehavior of the regulated party to the public at large, and possibly to take legal action. The "community-right-to-know" laws discussed above are one of the most powerful examples in modern law, but there are others. ${ }^{185}$

It is important to note that triangulation mechanisms place increased compliance pressures not only on regulatees, but also on regulators, whose performance can also be questioned. This creates some structural "balance" in a situation where regulators are responsible for protecting public interests, and is likely to improve the efficacy of the regulators in performing their functions. Another important factor is that the outsiders must have some leverage to challenge the effectiveness of the system in order to enhance its effectiveness. Typically, this means the capacity to inflict some kind of "bad" on poorly performing parties. T hird, of course, this process

183 IAN AYRES \& JOHN BRAITHWAITE, RESPONSIVE REGULATION: TRANSCEnding THE DeREgulation Debate (1992).

184 Barry Boyer \& Errol E. Meidinger, Privatizing Regulatory Enforcement: A Preliminary Assessment of Citizen Suits under Federal Environmental Laws, 35 BUFF. L. REV. 834, 834-965 (1985).

$185 \quad$ Karkkainen, supra note 146. 


\section{BUFFALO ENVIRONMENTAL LAW JOURNAL [Vol.10}

is likely to make forest certification more of a public phenomenon, and less a narrowly "professional" one.

Many different triangulation structures are possible for forest certification, and it is not feasible to propose or justify a specific one here. Rather, the key point is that to achieve reliable efficacy (and thereby adaptability and legitimacy) forest certification programs will likely need to empower third parties to monitor and challenge the performance of firms and programs. ${ }^{186}$ The third parties should be involved not only in the policy formation process, but also in the implementation process. Who they should be could vary among from one cultural and institutional context to another, but it seems clear that the issue will need to be worked out for certification to become a dependably effective process.

"Creative Compliance." Another dimension of forest certification that has received much thought by lawyers and some study by socio-legal scholars, but relatively little public discussion by forest certification experts is the problem of "creative compliance." If pressed, most lawyers would probably acknowledge that one of their most important roles is to help clients "work around" rules. Working around rules does not mean violating them, but rather finding ways to conform to them while sometimes attaining ends that the rules were probably intended to prevent. McBarnet and Whelan provide a number of informative case studies of how corporate lawyers have figured out ways to get around financial regulations, often with the tacit cooperation of accountants who enjoy institutionalized trust very similar to that accorded forest certifiers. ${ }^{187}$

186 In principle, it is possible that governmental agencies could play the triangulation role in some contexts. It seems unlikely, however, that those contexts will be ones where agencies are already heavily involved in certification, such as in Europe, since their interests are quite closely aligned with some certification programs, E.g., PEFC, supra note 64, and opposed to others, E.g., FSC, supra note 4.

187 Doreen McBarnet \& Christopher J. Whelan, Creative Compliance and the Defeat of Legal Control: The Magic of the Orphan Subsidiary, in THE HUMAN FACE OF LAW: ESSAYS IN HONOR OF DONALD HARRIS 177-198 (Keith Hawkins ed., 
Creative compliance seems to be an endemic tendency of rulebased systems, and there is no reason to think that forest certification systems will be free of the problem. I suspect that the main reason it has not received much thought to date is that the designers of certification systems are strongly inclined either to believe their rules will work, or at least not to question them too closely. Moreover, they may be somewhat naïve about the workings of traditional governmental regulatory programs. Eventually they will have to confront the problem, however. They will have to engage in the same kind of process that financial regulators are involved in, which is trying to adjust their rules to close off the loop holes that creative compliers have found and then watching for reports of new forms of

1997); DoreEn MCBARNET \& CHRISTOPHER J. WHELAN, CREATIVE ACCOUNTING AND THE CROSS-EYED JAVELIN THROWER(1999). The collapse of the energy trading corporation, Enron, in late 2001, evidently due in part to creative compliance with accounting rules approved by major accounting firm Arthur Anderson, might be taken as an exclamation point to this warning, which was written months before the collapse. However, the exact bearing of the Enron case on forest certification remains to be worked out. One of the commonly cited problems, the provision of both accounting and consulting services by Arthur Anderson, with the consulting as lucrative as the accounting work, may have given Anderson an added incentive to facilitate creative compliance. No evidence has come to my attention that there is a comparable problem in the forest certification context, although it is difficult to say with certainty. Most certification programs appear to have bans on certifiers providing consultancy services to firms they certify, but it is not out of the question that some of the experts retained by certification firms may have interests of some kind in the professional advice relied upon by certified forest enterprises. On the other hand, there is a type of accountability pressure present in the financial accounting world that is absent from or much weaker in the forest certification world, and that is the fact that stockholders who might be injured by accountant ratified overestimates of a stock's value will place considerable pressures on accountants to avoid such situations. Gretchen Morgenson, Scandal's Ripple Effect: Earnings Under Threat, N.Y. TIMES, Feb. 10, 2002, $\S 3$, at 1 . If an accounting firm got a reputation for approving questionable practices, its audits would lose value in the financial markets and its business would therefore be expected to decline. There are not likely to be comparable pressures from consumers of certified wood, although competitors might have incentives to police one another to some extent. 


\section{BUFFALO ENVIRONMENTAL LAW JOURNAL [Vol.10}

creative compliance. At present, however, as is further discussed in the "adaptation" section below, forest certification systems seem poorly equipped to deal with this challenge. They are not organized to systematically collect information on creative compliance. No one in the system has that function.

\section{External}

The fact that certification programs operate in a larger regulatory arena, often competing and cooperating with one another and with governments, means that they can also achieve efficacy by influencing other programs. First, and most obviously, there is reason to believe that more rigorous certification programs, such as the FSC, have spurred significant improvements in less rigorous ones, such as the SFI; ${ }^{188}$ a moderately optimistic analysis holds that this dynamic is likely to occur to certification programs generally. ${ }^{189}$ Less obviously, certification programs may also have broader external effects by stimulating improvements in governmental environmental regulation and promoting increased consistency among jurisdictions.

Improved Governmental Regulation. Forest certification programs have the attention of governmental forestry agencies in most of the world. Some government management agencies have chosen to seek certification of the lands they manage under one program or another. Others, particularly in Europe and Asia, have formed alliances with specific certification programs.

Even where governments are officially detached they are likely to be influenced in various ways by certification programs. First, as noted above, certification programs are likely to bring public attention to how well government agencies are doing their work, and may possibly spur them to improve. Second, the larger discussion of forestry standards and practices stimulated by certification processes

188 Meidinger, supra note 4.

$189 \quad$ Fung et al., supra note 47. 
is likely to infuse governmental legal requirements in various ways, including changes in formal rules and informal implementation practices, as well as standards imposed by courts and other agencies. ${ }^{190}$

In Bolivia the FSC-oriented standard setting process undertaken by a non-profit civil society organization led not only to the creation FSC national standards, but also to revisions of government requirements, which ended up being effectively the same. The government regulations aiso recognize FSC certified forestry operations as complying with forest laws. ${ }^{191}$

Third, government agencies could simply require certification as a condition of conducting forestry in their jurisdictions, as some have done already, ${ }^{192}$ thus significantly expanding their total implementation capacity. There are intermediate options as well. For example, when Guatemala makes a land concession to a community forestry group in the Biosphere Reserve it requires the group to obtain FSC certification within three years, ${ }^{193}$ apparently as a condition of retaining the concession.

Even if they do not formally require certification, government agencies could concentrate their enforcement on uncertified firms, treating certified ones as likely to be in compliance. Again, this would effectively expand total enforcement resources and presumably lead to improved overall compliance. ${ }^{194}$ Governments could even seek to

\footnotetext{
190 See generally Meidinger, supra note 4.

191 William Cordero, Forest Certification and Law in Bolivia, Presentation to the International Conference on Social and Political Implications of Forest Certification (Jun. 20-22, 2001) (video on file with author).

192 Meidinger, supra note 4.

193 Andrea Finger-Stitch, Community Concessions and Certification in the Maya Biosphere Reserve, in SOCIAL AND POLITICAL DIMENSIONS OF FOREST CERTIFICATION 165 (Errol E. Meidinger, Christopher Elliott and Gerhard Oesten, eds., 2003).

194 Interestingly, the degree to which this has occurred to date is unclear. The U.S.E.P.A. evidently has increased the resources it expends on defining and managing the "Performance Track" program, for example, but there is little evidence that it has shifted enforcement resources to monitoring firms that are not in the program. COGLIANESE \& NASH, supra note 12, at 231-2.
} 
leverage their overall resources by attempting to 'steer' certification programs, as they are doing to a limited degree already. ${ }^{195}$ This strategy might be one of the ways in which states gradually redefine their regulatory roles, increasingly incorporating civil society regulatory programs where they can, and focusing their own efforts on areas where certification programs are less helpful.

It should be noted however, that any obvious increased government involvement in or reliance on certification programs is likely to trigger back-pressure by industry on certification programs. Thus, there might be increased pressure for lower standards and less expensive, weaker inspection practices, as evidently has been the case with the PEFC.

Inter-Jurisdictional Consistency. As a global movement, forest certification automatically creates new channels of communication and comparison across national boundaries. If in fact it has the influence on governmental regulatory standards and practices posited above, certification has the potential to promote increased regulatory consistency and convergence among jurisdictions, both governmental and non-governmental. Although this possibility is subject to the logical challenges of coherence discussed below, it is a goal high on the agenda of both environmental organizations and many transnational businesses, who see advantages to consistent rules across jurisdictions. At present, there remains enormous variability among. national systems and different certification systems, but the possibility exists that together they will serve as conduits for convergence over time.

\section{Adaptability}

Ultimately, forest certification will be efficacious only to the extent that it promotes sustainable forest management. Promoting

195 Kernaghan Webb, Voluntary Initiatives and the Law, in VOLUNTARY INITIATIVES: THE NEW POLITICS OF CORPORATE GREENING 32, 33 (Robert B. Gibson, ed., 1999). 
sustainability will not be a simple matter of implementing existing rules and standards. First, there is inevitably much we do not know about how to achieve sustainability. Second, those subject to certification programs will often practice "creative compliance." Third, rule systems generally have unanticipated consequences as great or greater than the intended ones. ${ }^{196}$ Therefore, such systems need to be adaptable.

In essence the challenge of adaptability is a challenge of learning- specifically, learning to solve emergent problems. ${ }^{197}$ Forest certification programs face major challenges regarding how to institutionalize learning. Perhaps because they have conceptualized themselves so much as rule systems, and because there has been so much contention about the content of the rules, they do not seem to have taken seriously the problem of gathering and analyzing information about their own performance and how they can improve it.

The primary need is to create feedback loops from groundlevel experience to system-level policies. The major repositories of ground level information, certifiers, do not seem to have incentives or resources to share information on implementation experiences or to gather systematic information. Indeed, since they compete with each other, certifiers may have disincentives to share anything beyond the trivial or obvious. Management organizations are also in competition with each other, and would seem to have equally few incentives to share information, particularly when it might cost them money. As forest certification is presently constituted, no other interests have the capacity to gather detailed information on ground level experience.

This situation could change if some of the suggestions for transparency and triangulation made above were to be adopted. It probably must change if forest certification is to become sufficiently adaptive to remain viable over the long term. The fact that the problem has not been more carefully addressed to date seems particularly unfortunate given the potential envisioned by some

\footnotetext{
196 JONES, supra note 169.

$197 \quad$ LEE, supra note 89.
} 
observers for transnational NGOs to become agents of global social learning. ${ }^{198}$ If this potential is realized, it is likely to be a major development in the capacity of global civil society to circumvent some of the severe limitations of the Westphalian governance system.

\section{Coherence}

From the perspective of legal theory, forest certification, particularly as exemplified by the FSC, is a stunningly ambitious undertaking. It seeks to create a set of rules and institutions for forest certification that (1) integrate environmental, social, and economic goals, (2) apply them consistently across boreal, temperate and tropical forests, in (3) developed and developing regions with vastly different institutional arrangements and cultural traditions. One may pause simply to wonder whether any rational actor would undertake such a profoundly difficult task. Of course a skeptic might quickly observe that perhaps the ambitions of forest certification are not as great as they seem. Actually, what forest certification needs to achieve is an acceptable image of globally consistent rules rather than the "reality". ${ }^{199}$ This is also what most global traders would want-a system in which the fundamental qualities of products are not subject to question.

Regardless of whether the ambitions of forest certification are truly staggering, or merely unprecedented, they are worth following closely. The Westphalian system has been utterly incapable of fulfilling either vision. All legal systems should therefore pay close attention to how forest certification fares. If forest certification makes significant progress there is much to be learned from it, both about how to make rules and about the emergent role of global civil society. In this section my goal is primarily to clarify some of the challenges of coherence posed by such a grand set of goals, and secondarily to offer a few observations about what is being done to meet them.

\footnotetext{
198 E.g., Finger, supra note 71, at 65.

199 Jack N. Balkin, Understanding Legal Understanding: The Legal Subject and the Problem of Legal Coherence, 103 YALE L. J. 5, 5-75 (1993).
} 


\section{Integration}

As noted above, the core goal of integration involves incorporating environmental, social, and economic goals in the same set of standards. This general approach is supported by the increasingly commonplace view, promoted for about two decades now, that one cannot have a healthy environment without a healthy economy and society, and vice versa. Of course, these concerns have largely been kept separate in traditional legal and regulatory systems. The FSC forest certification program thus attempts to break new ground. Initially, it seeks to do so by addressing the various concerns in individual principles. In practice, however, the principles must be accommodated with each other not only in regional standard setting processes, but also, and probably more importantly, in the course of each certification decision. How much responsibility for protecting the environment, for example, can firms be required to carry when they are also enjoined to remain economically viable in a market where not all firms are certified? Similarly, what provisions are sufficient to protect indigenous rights, given that clear adjudications could take a long time in many places, and possibly negate the economic viability of certain enterprises?

These questions have been handled largely in individual certification processes to date, occasionally with considerable public conflict, but mostly below the radar screen. The ideal of the FSC (and derivatively of the PEFC), however, has been that regionally-based stakeholder standard-setting processes will provide contextually appropriate answers, reflecting regional culture and values. Making the tradeoffs in this way implies a culturally based coherence supported by the reasoning developed in decision process.

This is fairly similar to traditional democratic justifications for law as well as to Habermas' dialogic model, ${ }^{200}$ but it faces several problems. First, of course, it is possible that the tradeoffs would have

\footnotetext{
200 Jurgen Habermas, The Structural Transformation Of The PUblic SPHERE (1989).
} 


\section{BUFFALO ENVIRONMENTAL LAW JOURNAL [Vol.10}

been quite different if different people had participated in the standard setting process, as has been asserted for example in the FSC Canadian Maritime standard setting case. There the timber industry claimed that the standards were inappropriate because they were developed without sufficient industry input, and was partially sustained by an investigating commission. ${ }^{201}$ While this can be described as a problem of stakeholder theory, it also affects the ideal of coherence, since it may be that regional values simply do not and are not likely to fit together in many situations. Legal theorist Joseph Raz suggests that this is a problem with all efforts to privilege conceptual coherence in law. ${ }^{202}$

This problem becomes much more serious when the global scope of the system is considered. The promise of forest certification is that a piece of certified wood from Malaysia is the environmental and social equivalent of a piece of certified wood from Sweden. For this to be the case one of two conditions must be met. Either "equivalent" must mean merely that a regional standard has been set in each case and that each piece of wood meets the applicable regional standard (avoiding for the moment the problem of setting a standard for what constitutes a legitimate standard setting process). Or, there must be some logical relationship between the standards making them comparable within a larger framework. Most forest certification programs are strongly committed to the second principle, although they vacillate on how to meet it. The environmental NGO Fern, for example, argues that one reason performance based systems are necessary for certification is that only they can achieve coherence. Environmental management system standards, by contrast are fundamentally incapable of achieving coherence. ${ }^{203}$

The commitment of forest certification programs to coherence reflects an underlying assumption that there is globally common

201 GEMMA BOETEKEES ET AL., FSC COMMISSION OF ENQUIRY, FOREST STEWARDSHIP STANDARDS FOR THE MARITIME FOREST REGION: FINAL REPORT (2000) (on file with author).

202 Joseph Raz, The Relevance of Coherence, 72 B.U. L. REV. 273, 310 (1992).

203 FERN, BEHIND THE LOGO: AN ENVIRONMENTAL AND SOCIAL ASSESSMENT OF FOREST CERTIFICATION SCHEMES at 17 (2001) (on file with author). 
standard for proper forest management, and that it is possible for forest certification programs to certify it. The assumption of a common moral standard seems to apply equally to the global civil society movement. Thus forest certification in particular and global civil society in general are faced with the need to create coherence in order to advance their causes. I will not predict whether or how they will do it-only that they will and must try. One route is for certification programs to promote master metaphors, such as "ecosystem health" and "sustainable forestry"204 and position themselves to be the ones who progressively fill those metaphors with concrete meaning. It will be interesting to compare the process with developments in international commercial arbitration ${ }^{205}$ and computer operating systems, ${ }^{206}$ where competitive informal definitional processes seem to have been key, with forest certification, which seems to lean toward more formal arrangements.

It will also be interesting to observe to what extent variations in specific standards can be reconciled with the requirement of coherence. Can the FSC, for example, effectively persuade people that requiring elaborate protective equipment for adult workers in Swedish certified forests is equivalent to allowing barefoot twelve-year-olds to work in third world certified forests, where if they do not do so their families they may starve? How will this be done? The current debate within the forest certification world will eventually have to find a social reception outside it. In doing so it may have to develop a persuasive account of how facially different regional standards should be seen as effectively consistent.

20, E.g., Margaret A. Shannon et al., Science Advocacy is Inevitable: Deal With it, in ProceEdings OF THE SOCIETY OF AMERICAN FORESTERS ANNUAL CONFERENCE (1996).

${ }_{205}$ DEZALAY \& GARTH, supra note 124.

206 LAWRENCE LESSIG, CODE AND OTHER LAWS OF CYBERSPACE (1999). 


\section{Federalism}

The FSC is organized to address the problem of regional challenges to coherence primarily with a system of closely coordinated federalism. The primary processes involved are central review of regionally developed standards for conformance with the international principles and criteria, and inter-regional "harmonization" processes. A number of examples of each are now complete, and will undoubtedly be subjected to intensive review. From the perspective of legal scholarship, the harmonization processes are fascinating. While there are some guidelines for how they are to be carried out, they seem to vary greatly from one region to the next. This is not to say that they will not work well, only that a theory of why they work well will have to be developed after the fact. ${ }^{207}$

Moreover, if one compares these harmonization processes to traditional Westphalian ones, they could come out looking fairly good. It is quite possible that NGOs and certification programs link levels and regions much more successfully than governments. They also benefit from a narrower set of concerns. The Maritime region's view of the Great Lakes region's herbicide policy, for example, is not dependent on the Great Lakes region's position on software sales to the Maritime region. Global Civil Society programs also benefit from rapid communications technologies, less cumbersome decision procedures, and (perhaps) less turf wars. Moreover, it is not inherently obvious that they are less "democratic" than Westphalian decision systems, ${ }^{208}$ given the all of the well known shortcomings of governmental decision making. All in all, then, if coherence can be achieved,

207 To date, the PEFC has devoted considerably less resources than the FSC to the problem of inter-regional harmonization, and indeed seems to start from the assumption that all European standards are fundamentally comparable. As Eckhard Rehbinder, Forest Certification and Environmental Law [cite from TOA] points out, the FSC is not free of the problem, in that many of the regional standard setting bodies are organized according to national boundaries, thus suggesting a potential "renationalization" of standards. Nor is his critique vitiated by the fact that the larger nations include multiple regional standard setting bodies.

208. Finger, supra note 71 , at 58. 
there is some reason to think that civil society organizations are in a plausible position to do so.

The main shortcomings of global civil society regulatory programs are their incapacity to raise taxes and conduct wars- not minor defects, but perhaps not as important as they once were. Though poorly funded and under staffed, these small programs made up of relatively well informed participants who communicate regularly may have better prospects of achieving closure in the harmonization process than non-expert legislatures with much broader issue portfolios. Finally, it is worth noting that the nitty-gritty details in the harmonization and central review processes are being worked out for the most part by foresters and environmentalists, rather than lawyers. While they are not trained for the job, neither are most lawyers, and it will interesting in any case to learn from their experience.

\section{(In)Determinacy}

Indeterminacy refers to a condition in which rules, often quite elaborate ones, do not generate determinate outcomes in particular cases. Thus, one can take a given factual situation, apply the rules to it, and reach more than one logically justified conclusion. In the certification situation, this would mean that the same forest enterprise could be seen as either certifiable or not certifiable depending on how the rules are applied. Some, but not all, legal scholars see indeterminacy as a flaw in coherence and an inherent limitation of all rulebased systems. One common maxim is that the more factors a legal agent is allowed or required to consider, the less determinate her decision will be. In practice the situation is probably more complicated, depending on the nature and magnitude of the factors at issue. But it is worth bearing in mind in the certification context.

I mention the issue for two reasons. First, anecdotal experience suggests that despite the elaborate systems of rules that have been developed in many regions (perhaps particularly in the U.S.), certifiers still seem to feel they must exercise a great deal of "professional judgment" going beyond the rules in making individual certification 
determinations. Second, these conditions seem to apply even in much more rule intensive (or "juridified") arenas such as administrative regulation. Hence, the tendency of certification programs to promulgate growing numbers of rules, criteria, and indicators is not likely to resolve the problem of indeterminacy. Accordingly, the programs should probably consider whether they would be better off simply publicizing and attempting to explain the role of professional judgment in their operations.

\section{Legitimacy}

No legal system can endure for long, or be broadly effective, relying solely on coercion. Rather, it must enjoy voluntary compliance by the great majority of persons subject to it. In attempting to understand why and when legal systems are successful, much sociolegal research has focused on how they build voluntary compliance. Given that certification systems have very little coercive capacity, this research is particularly relevant to them. Perhaps the most widely relied upon concept in explaining legal compliance has been that of legitimacy. Max Weber argued that a legal system has legitimacy when it can, without using coercion, elicit compliance with its rules or decisions even from people who disagree with the substance of those rules or decisions. ${ }^{209}$ This is the "pull toward compliance" referred to above. ${ }^{210}$ The degree of legitimacy enjoyed by forest certification today is unclear, and in fact is deeply contested. ${ }^{211}$ Some

\footnotetext{
209 WEBER, supra note 104, at 31.

210 Whether and when legal systems actually function in this way is a difficult question about which I make no assumptions here. As Alan Hyde has pointed out, it may be a mistake to assume that legal systems generally enjoy legitimacy. Alan Hyde, The Concept of Legitimation in the Sociology of Law, 1983 WIS. L. REV. $379,379-426$ (1983). It is quite possible that behavior described as being based on legitimacy is actually based on self-interest or other functional considerations. On the other hand, as Franck's scholarship makes clear, it is difficult to understand many developments in international law without the concept of legitimacy. FRANCK, supra note 131.

$211 \quad$ Cashore, supra note 67.
} 
observers, echoing my long-ago conversation with Professors Lyons and Mohawk, think it inevitable and only a matter of time until the obvious rightness of certification wins the day. Others view certification as a fundamentally coercive phenomenon. One industry representative told me bluntly that "proper forest management is what the FSC says it is ... nothing more, nothing less." His point was that the reason his company would maintain FSC certification was simple economic self-preservation. It could not afford to get a bad name in its markets, and the FSC and its allies were capable of giving it a bad name. Other company representatives have of course said the opposite, and talked about the basic correctness of the FSC or other certification standards.

For now, it appears that the legitimacy of forest certification programs is largely derivative and depends largely on the credibility of the groups affiliated with them. Thus the FSC program relies primarily on the public legitimacy of environmental (and to a lesser extent labor and human rights) NGOs, while other programs rely more on the somewhat uncertain legitimacy of the forestry profession, industry, and state agencies. Over time, however, the dynamics of legitimacy are likely to become more general, and certification systems will have to develop their own legitimacy. Whether that is happening and how is currently an open question subject to ongoing research. ${ }^{212}$ By their nature, however, certification systems face two especially intriguing problems of legitimacy, with which I close this paper.

The first problem has to do with certification programs' reliance on market relationships and consumer preferences to organize governance institutions. This strategy may give up one of the traditional legitimacy advantages enjoyed by civil society organizations, which Ann Phillips describes as having a much greater capacity to "capture people's hearts and minds" 113 than do governments. Assuming that her assessment is accurate, it is worth pondering the

\footnotetext{
$212 \quad I d$.

213 Anne Phillips, Who Needs Civil Society? 46(1) DiSSENT 56, 58 (1999).
} 
implications of the use of marketing techniques to organize civil society relationships. Might this strategy inherently reduce the depth and durability of commitment to civil society norms? Might it reframe the background in which civil society actors are seen so that their views have the same ontological status as all other individual consumer tastes? If so, the use of market methods could create considerably greater difficulties than are currently apparent for legitimizing certification institutions over the middle and long term.

The second legitimacy challenge has to do with the global reach of forest certification programs. To date, the primary focus of certification systems has been on retailers and consumers in wealthy countries. In a global civil society, however, they will have to legitimate themselves simultaneously with poor, third world woods workers and villagers as well as with relatively well off northern workers. This is a challenge that no governmental or intergovernmental body has come close to meeting. If certification programs in fact achieve anything approximating north-south, inter-class, intercultural legitimacy, they will have pulled off an organizational feat unprecedented in human law and governance. Ultimately, however, even if they are successful in establishing global legitimacy, we will not know for some time whether they thereby function to challenge and supplant governmental legal systems, or in fact to extend and amplify them. 